$5-7-2020$

\title{
Chomsky and Genocide
}

Adam Jones

University of British Columbia Okanagan

Follow this and additional works at: https://digitalcommons.usf.edu/gsp

\section{Recommended Citation}

Jones, Adam (2020) "Chomsky and Genocide," Genocide Studies and Prevention: An International Journal: Vol. 14: Iss. 1: 76-104.

DOI:

https://doi.org/10.5038/1911-9933.14.1.1738

Available at: https://digitalcommons.usf.edu/gsp/vol14/iss1/8

This Articles is brought to you for free and open access by the Open Access Journals at Digital Commons @ University of South Florida. It has been accepted for inclusion in Genocide Studies and Prevention: An International Journal by an authorized editor of Digital Commons @ University of South Florida. For more information, please contact digitalcommons@usf.edu. 


\title{
Chomsky and Genocide
}

\author{
Adam Jones \\ University of British Columbia Okanagan \\ Kelowna, British Columbia, Canada
}

\section{Introduction}

Avram Noam Chomsky (1928-) may be the most prominent and significant public intellectual of the post-World War Two period. His contributions to linguistic theory continue to generate debate and controversy. But two generations know him primarily for his political writings, public talks, and other activism, voicing a left-radical, humanist critique of US foreign policy and other subjects. Works such as American Power and the New Mandarins (1969, on Vietnam and US imperialism more generally), The Fateful Triangle: Israel, the US, and the Palestinians (1983), James Peck's edited The Chomsky Reader (1987), and 1988's Manufacturing Consent: The Political Economy of the Mass Media (co-authored with Edward S. Herman) hold a venerated status for leftist/progressive readers. His mini-book 9/11, published in the wake of the 2001 terrorist attacks on New York and Washington, became a surprise bestseller (over 115,000 copies shipped in the first six months). ${ }^{1} \mathrm{~A}$ handful of widely-seen documentaries have further spread his renown. ${ }^{2}$

Given the centrality of a human-rights and mass-violence critique in Chomsky's political output, as well as its voluminous quantity over fully half a century, it is appropriate to inquire about the place of "genocide" 3 in his analysis. After encountering some scattered mentions in his books and published interviews over the years, I resolved to undertake such an inquiry. My interest was further piqued when I realized that genocide, though marginal to Chomsky's critique, is touched upon in literally dozens of his books, as well as other writings and interviews available (and searchable) online. Its treatment is usually passing and fragmentary, but from these fragments, a composite portrait can be assembled of the deployment of "genocide" in Chomsky's extensive canon.

I approached my task by searching for appearances of "genocide" and "genocidal" in the digital texts of 61 books by or featuring Chomsky (sometimes edited by others). At least one of these terms appeared in roughly two-thirds of the volumes, though some of these were repeated/reprinted materials. I also conducted a separate search for "holocaust," to arrive at an understanding of how Chomsky deploys both the Jewish Holocaust and the generic label "holocaust" in other contexts. With the exception of the Chomsky/Herman pamphlet, Counter-Revolutionary Violence: Bloodbaths in Fact and Propaganda (1973, subsequently withdrawn and suppressed by the publisher), ${ }^{4}$ all quotes from digital sources that were not facsimiles of a printed edition were cross-checked against the printed versions, and the latter are the page references supplied. Some additional comments were found in online sources, especially interviews with Chomsky, and these are cited in the notes.

The key questions to be addressed here include: How does Chomsky define, understand, and criticize "genocide"? How does his interpretation compare with the legal definition in the UN Genocide Convention, and framings in comparative genocide studies? Which historical and contemporary cases does he consider to be emblematic or paradigmatic of genocide? Are ambiguities, hesitations, and inconsistencies evident in his use of the term? And how does the language of " $\mathrm{H} /$ holocaust" figure in his discourse?

Several caveats are in order. First, although I have delved deeply into Chomsky's published output on political themes, this study does not constitute a formal, statistically-guided content

\footnotetext{
${ }^{1}$ Michael Massing, “Think Tank: Surprise Best Seller Blames US," The New York Times, May 4, 2002, accessed March 23 , 2019, http://www.nytimes.com/2002/05/04/books/think-tank-surprise-best-seller-blames-us.html.

${ }^{2}$ Most notably Manufacturing Consent: Noam Chomsky and the Media (dir. Mark Achbar and Peter Wintonick, 1992, available online at https://www.youtube.com/watch?v=AnrBOEAM3rE); Requiem for the American Dream (dir. Kelly Nyks et al., 2015, available online at https://www.youtube.com/watch?v=wp6Rbgv1MLg).

${ }^{3}$ Throughout this article, I use "genocide" in quotation marks to refer to discursive/rhetorical uses of the term, rather than actual or alleged cases of genocide.

${ }^{4}$ See the Wikipedia article on Chomsky and Herman's “Counter-Revolutionary Violence: Bloodbaths in Fact and Propaganda," accessed March 30, 2019, https://en.wikipedia.org/wiki/Counter-Revolutionary Violence: Bloodbaths in Fact \%26 Propaganda.
} 
analysis. Rather, my approach is qualitative, seeking to discern a range of regularities (and some irregularities) in Chomsky's references to "genocide," from his earliest essays to recent times. The intention is to provide an overview of how an iconic public intellectual has engaged with one of the iconic concepts and issues of the age.

Second, some of Chomsky's output is coauthored, most notably with Edward S. Herman (to whose separately coauthored volume, The Politics of Genocide, Chomsky contributed a highly relevant foreword) and the Israeli scholar Ilan Pappé. Importantly, both these authors seem substantially more disposed than Chomsky himself to use the "genocide" term and framework. In the latter case, I have excluded passages from coauthored volumes where the usage clearly originates with Pappé. Such distinctions are harder to draw with the Chomsky/Herman coauthored works, notably the two-volume Political Economy of Human Rights (comprising The Washington Connection and Third World Fascism and After the Cataclysm) and the book that, probably more than any other, is associated with Chomsky: Manufacturing Consent.

Third, Chomsky has over the years been the subject of controversy for stances taken with regard to Holocaust denialists' right to free speech (most notably in the "Faurisson affair"), Khmer Rouge genocide in Cambodia, ${ }^{6}$ and the genocide of Rwandan Tutsis in 1994. I played a part in the last of these, ${ }^{7}$ but in the present context, I am interested in them only insofar as they generated statements and written passages by Chomsky that are directly pertinent to this analysis.

Lastly, I should acknowledge a longstanding personal relationship with Chomsky, extending back to my first reading of his work in the mid-1980s and subsequent correspondence with the author. My first published book, Beyond the Barricades, ${ }^{8}$ was dedicated to him, and I have regularly acknowledged him in print as a formative intellectual and moral influence. ${ }^{9}$ My correspondence with him lasted for roughly a quarter-century, including dozens of exchanges. (There is nothing very unusual about this: Chomsky is famous for engaging in written exchanges with mostly ordinary individuals worldwide.) In 1990, I met and interviewed him at his office at the Massachusetts Institute of Technology and was invited to a meeting of activists at his home in Lexington, Massachusetts, where I also met his late wife Carol. I worked alongside Chomsky's daughter, Diane, in Managua while conducting research at the offices of the Sandinista paper Barricada for my M.A. and Ph.D. theses, which formed the basis of the Beyond the Barricades volume.

This article is therefore unlikely to be a hit-piece of the kind that others have regularly crafted to attack Chomsky ${ }^{10}$ - but neither is it a hagiography. In strongly criticizing Edward Herman's coauthored The Politics of Genocide for its reprehensible denial of the Tutsi genocide in Rwanda, I have also decried Chomsky's decision to attach a foreword to that book, and I offered advice and guidance to two critics (Roland Moerland and George Monbiot) in their extended correspondence with him on the subject. ${ }^{11}$ I hope a critical approach will be evident in my observations here, but if I have overlooked any notable elements - whether because of my political and personal sympathies for Chomsky, or through deficiencies of insight and observation - I welcome contributions and corrections by others. My thanks to Melanie O'Brien and Jo Jones for feedback and proofreading.

\footnotetext{
${ }^{5}$ See, e.g., Richard Eder, "Chomsky Stirs French Storm in a Demitasse," The New York Times, January 1, 1981, accessed March 23, 2019, http://www.nytimes.com/1981/01/01/world/chomsky-stirs-french-storm-in-a-demitasse.html.

${ }^{6}$ See, e.g., Donald W. Beachler, "Arguing about Cambodia: Genocide and Political Interest," in The Genocide Debate: Politicians, Academics, and Victims by Donald W. Beachler (Basingstoke: Palgrave Macmillan, 2011), 35-58.

${ }^{7}$ See Adam Jones, "Denying Rwanda," in The Scourge of Genocide: Essays and Reflections by Adam Jones (London: Routledge, 2012), 346-359, available online at http://jonestream.blogspot.ca/2010/11/denying-rwanda-response-toherman.html.

${ }^{8}$ Adam Jones, Beyond the Barricades: Nicaragua and the Struggle for the Sandinista Press, 1979-1998 (Athens: Ohio University Press, 2002).

${ }_{9}^{9}$ See, e.g., Adam Jones, preface to Gender Inclusive: Essays on Violence, Men, and Feminist International Relations by Adam Jones (London: Routledge, 2009), xi-xix; Adam Jones, "Seized of Sorrow," in Advancing Genocide Studies: Personal Accounts and Insights from Scholars in the Field, ed. Samuel Totten (New Brunswick: Transaction Publishers, 2015), 5777 .

${ }^{10}$ See, e.g., David Horowitz, “The Sick Mind of Noam Chomsky," Salon.com, September 26, 2001, accessed March 23, 2019, https://www.salon.com/2001/09/26/treason 2/.

${ }^{11}$ Moerland's correspondence with Chomsky about the Rwandan genocide was posted to his blog, but that blog (rolandmoerland.blogspot.ca) appears to have been taken down. Monbiot's "Correspondence with Noam Chomsky" can be found at http://www.monbiot.com/2012/05/21/2181/ (accessed March 23, 2019). See note 69, below.
} 


\section{Defining "Genocide"}

Given that the term appears regularly in his output, with both support and criticism for its usage, Chomsky has engaged with the "genocide" concept surprisingly rarely - perhaps mainly when prodded to do so by interviewers such as David Barsamian, or by a collaborator's solicitation (I am thinking of Chomsky's foreword to The Politics of Genocide). Given the ambiguities and (as I will show) inconsistencies that arise in his deployment of "genocide," his definition and understanding of the concept must be inferred rather than simply cited.

Some of his most detailed and intriguing comments on the subject came in an interview with Barsamian, a community-radio figure whose conversations with Chomsky have formed the basis of numerous books. The relevant passages appear in the UK edition of Class Warfare:

Barsamian: I know on Bosnia you received many requests for support of intervention to stop what people called "genocide." Was it genocide?

Chomsky: "Genocide" is a term that I myself don't use even in cases where it might well be appropriate.

Barsamian: Why not?

Chomsky: I just think the term is way overused. Hitler carried out genocide. That's true. It was in the case of the Nazis-a determined and explicit effort to essentially wipe out populations that they wanted to disappear from the face of the earth. That's genocide. [Note: all emphases are added.] The Jews and the Gypsies were the primary victims. There were other cases where there has been mass killing. The highest per capita death rate in the world since the 1970s has been East Timor. In the late 1970s it was by far in the lead. Nevertheless, I wouldn't call it genocide. I don't think it was a planned effort to wipe out the entire population, though it may well have killed off a quarter or so of the population. In the case of Bosnia - where the proportions killed are far less - it was horrifying, but it was certainly far less than that, whatever judgment one makes, even the more extreme judgments. I just am reluctant to use the term. I don't think it's an appropriate one. So I don't use it myself. But if people want to use it, fine. It's like most of the other terms of political discourse. It has whatever meaning you decide to give it. So the question is basically unanswerable. It depends what your criteria are for calling something genocide. ${ }^{12}$

A number of insights can be gleaned from this exchange. The first is Chomsky's obvious hesitation and skepticism with regard to the "genocide" label - not least because of its vagueness and imprecision ("It has whatever meaning you decide to give it"), as well as its politicization, a subject I explore in detail later.

To highlight some key vocabulary in Chomsky's comments, he appears to assert that genocide represents a "planned," "determined," and "explicit effort" to exterminate ("wipe out") given "populations" whose "disappear[ance] from the face of the earth" perpetrators hold to be desirable and/or necessary. His deployment of Nazi genocide grants it primacy, perhaps uniqueness in the historical record, though as we will see, one other clear-cut case of genocide is regularly mentioned in Chomsky's work, and others are cited with qualifications.

Notable as well in the passage is Chomsky's distinction between "genocide" and "mass killing," with East Timor and Bosnia cited as examples of the latter. What distinguishes them, apparently, is the quantitative scale and totalizing exterminatory character of the genocidal enterprise. Chomsky's framing is thus in line with the "hardest," meaning most restrictive and exclusionary, of genocide definitions in the existing scholarship.

To flesh out Chomsky's understanding, it is worth citing statements included in a CityTVToronto news report on protests by Cambodian refugees against one of his speaking appearances. Chomsky referred to "the standard picture in the media" that the Khmer Rouge, under Pol Pot's leadership, "had taken credit for - had boasted, in fact - of having killed two million people in

${ }^{12}$ Noam Chomsky, Class Warfare (Monroe: Common Courage Press, 1996), 159. 
a unified, mass genocide campaign."13 In Chomsky's framing, the word "unified" seems to buttress the "planned"/centrally-directed aspect of true or full genocide, while the "mass" also hints at its totalizing, or at least extremely largescale character. In this context, note also Chomsky's qualification of the East Timor atrocities in Turning the Tide. As we will see, Chomsky cites the Indonesian mass killing in Timor as perhaps the closest post-World War Two parallel to Nazi genocide, but adds that "some barriers were placed in the way of the consummation of genocide" - again suggesting that genocide, to qualify as such, must be "consummated," i.e. fully or nearlyfully exterminatory. ${ }^{14}$

In addition to meshing with more limited and exclusionary framings of "genocide," Chomsky's totalizing emphasis is at odds with the definition advanced in the 1948 United Nations Convention on the Prevention and Punishment of the Crime of Genocide, with its well-known but imprecise phrasing of "destruction ... in whole or in part." On at least one occasion, in For Reasons of State, Chomsky has acknowledged the distinction. Stating that "some may be reluctant (as I have been personally) to use such terms as 'genocide"' with regard to US crimes in Indochina, he added in a footnote: "The question whether the term is technically appropriate, in the light of the United Nations Convention of 1948 , is a different matter." 15

What of the distinguishing characteristics of the "populations" targeted by (genuine/full-scale) genocide - especially regarding the four protected groups in the Genocide Convention? I am not aware of a specific comment on this subject, but based on my general survey of Chomsky's usage, they seem parallel with the "national," "ethnic," and "racial" groups - though not religious groups - protected under the Convention. Chomsky's references to genocide as a possible consummation of structural and institutional forms of violence might lead us to add a class component to the mix that is, the mass extermination of the poor by the privileged. I consider this aspect in greater detail below. Likewise, Chomsky's attention to the mass killings in Indonesia in 1965-66-targeting actual or alleged members and supporters of the Indonesian Communist Party (PKI) - and in Central America during the 1970s and 1980s (El Salvador and Nicaragua, as distinct from Guatemala) suggest an openness to including political targets of proto-genocidal or quasi-genocidal violence (overlapping, I sense, with social class/underprivilege). I know of no reference, however, to gender groups as targets of such violence.

\section{Genocide: Paradigmatic Cases}

In all of Chomsky's work that I have consulted, I find only one modern (post-Columbian) historical case that he has consistently and without qualification cited as "genocide," and another for which near-consistency and a nearly-complete absence of qualifications are hallmarks.

"The Nazi Holocaust"

I quote this phrasing ${ }^{16}$ to convey that Chomsky's understanding of Nazi policy and mass atrocities extends beyond the attempted destruction of European Jews. Chomsky is regularly at pains not to portray the Jewish Holocaust as unique. In particular, he has regularly stressed the comparable and contemporary genocide of the Roma/Gypsies and has referred to the Nazis' multiple "genocidal projects,"17 though without specifying them beyond the destruction of the Roma (Porajmos, or Devouring). In particular, I am unaware of any reference in this context to the Nazis' targeting for destruction of the Slavic peoples of Eastern Europe.

Nonetheless, Chomsky emphatically considers the "Nazi genocide"18 to be unique in the historical record. This is evident, and perhaps most explicit, in the lengthy passage from his conversation with David Barsamian, cited earlier (see note 12).

\footnotetext{
${ }^{16}$ Noam Chomsky, The Fateful Triangle: Israel, the United States, and the Palestinians (Montréal: Black Rose Books, 1984$), 94$.

${ }^{17}$ Noam Chomsky, The Culture of Terrorism (Boston: South End Press, 1988), 255.

${ }^{18}$ Noam Chomsky, Year 501: The Conquest Continues (Boston: South End Press, 1993), 71.
} 
His best-known (because frequently self-cited) description of the Nazi Holocaust, in Peace in the Middle East?, portrays it as "the most fantastic outburst of collective insanity in human history." ${ }^{19}$ In The Culture of Terrorism, Chomsky describes "the Nazi atrocities, needless to say," as "vastly beyond any comparison even to what we have been considering here" (i.e., various atrocities perpetrated by or with the complicity of the United States). ${ }^{20}$ Consider also this exchange with Barsamian:

Barsamian: I think, and I hope you'll agree, that what was radically different between what the Nazis did and what we [the US] did in Vietnam was the intent. The Nazis intended to exterminate the Jewish population of Europe. The intent in Vietnam was not genocide.

Chomsky: I'd never call what happened in Vietnam genocide. That's not the right term for it. I agree, it was totally different. I can't recall anyone suggesting otherwise. ${ }^{21}$ Actually, it's different in all sorts of respects. The Nazis really are historically unique. There have been a lot of atrocities in human history, but industrialized mass extermination of the style that the Nazis carried out is off the spectrum. There's just nothing that compares to it. The Jews and the Roma, the people we call Gypsies, were treated about the same way, and some other groups [n.b.]. That was unique..$^{22}$

Note that in this passage, the verdict of the Nazis' "historical uniqueness" and incomparability is based primarily on the unique strategy employed ("industrialized mass extermination"), rather than the elements of massive scale and near-total extermination (or intended extermination). But elsewhere, Chomsky has described Nazi genocide in more general moral terms as "probably the world's most horrifying atrocity." ${ }^{23}$ In his controversial foreword to Herman and Peterson's The Politics of Genocide, Chomsky quotes approvingly the authors' description of the Nazi genocide as "the crime of the $20^{\text {th }}$ Century for which the term originally was coined," and of applications of "genocide" to subsequent cases as excessively "frequent," "reckless," and "often ... debased."24 The effect of the authors' argument, Chomsky claimed, is to show that such usage "is an insult to the memory of victims of the Nazis." "25 Similar language is deployed in A New Generation Draws the Line, to dismiss applications of the "genocide" discourse to the Kosovo case. Such "propaganda," in Chomsky's view, constitutes "a form of Holocaust revisionism ... a bitter insult to the memory of Hitler's victims." 26

Chomsky's assertion of the specifically anti-Jewish component of the Nazi genocide is accompanied by biting critiques of the way the Shoah, in his view, has been exploited shamefully for political (especially pro-Israel) ends. This is considered in a separate section below ("The Holocaust: Memory and Propaganda"), where I point out Chomsky's regular pairing of the Shoah with the Porajmos, in which he emphasizes the distinct and highly politicized disparity in the attention accorded to each. What merits attention here is Chomsky's citing of the two atrocities in a way that stresses their essential comparability. "The Gypsies were treated just like the Jews in the Holocaust," he tells Barsamian in How the World Works, "but nobody's batting an eyelash about that because nobody gives a damn about the Gypsies." ${ }^{27}$ A comment included in the companion volume to the Manufacturing Consent documentary refers to "the Gypsies, who were killed at the same time, in the same manner, for the same reasons, and in about the same proportions" as the Jews. ${ }^{28}$ A slightly more extended version of the argument is found in another conversation with Barsamian:

Take the gypsies. Nobody supports the gypsies. You don't have to worry about alienating anyone. There isn't much study of the gypsies because nobody cares about them, and you know how everybody hates them anyhow, so they don't study it. But there is a Romani intelligentsia that's done research on the treatment of the Romani people by the Nazis and it looks pretty parallel to the way the Jews were treated. There are people who just flat out deny that in the most vulgar fashion. ${ }^{29}$

Thus, in contrast to some genocide scholars (e.g. Steven Katz, Yehuda Bauer) who favor a Holocaust uniqueness framework, Chomsky deploys something like a Nazi uniqueness framing, one that stresses the morally abysmal nature and systematically/industrially exterminatory strategy of Nazi crimes against Jews, Gypsies, and unspecified "other groups." 
Indigenous Peoples of the Americas

Only slightly less emphatically a case (or set of cases) of genocide, for Chomsky, is the destruction of the Americas' indigenous populations by both Anglo-American and Iberian invaders. Indeed, this is probably the context in which Chomsky most frequently and explicitly deploys the "genocide" concept. Typical references to this "notable chapter in the history of genocide" 30 include the following:

Here in the United States, we just committed genocide. Period. Pure genocide. And it wasn't just in the United States, it was all up and down the Hemisphere. ... Throughout American history this genocide has been accepted as perfectly legitimate. ${ }^{31}$

[The indigenous population was] slaughtered, decimated, and dispersed in the course of one of the greatest exercises in genocide in human history. ... In short, mass genocide [occurred], on a colossal scale, which we celebrate each October when we honor Columbus - a notable mass murderer himself - on Columbus Day. ${ }^{32}$

Spanish explorers set about what Tzvetan Todorov calls "the greatest genocide in human history" after they "discovered America" 500 years ago. ${ }^{33}$

In the Andean region and Mexico there were very extensive Indian societies, and they're mostly gone. Many of them were just totally murdered or wiped out, others succumbed to European-brought diseases. This is massive genocide, long before the emergence of thetwentieth century nation-state. It may be one of the most, if not the most extreme example from history, but far from the only one. These are facts that we don't recognize. ${ }^{34}$

As these passages suggest, Chomsky's emphasis on genocide in the Americas, and particularly in the United States, ${ }^{35}$ reflects his conviction that not only do these atrocities not arouse the same revulsion as Nazi genocide, but they are standardly suppressed and denied in mainstream discourse, ${ }^{36}$ addressed in a qualified or ambivalent fashion, and even positively commemorated and openly celebrated. ${ }^{37}$ In this sense, their contemporary political significance and the moral lessons to be drawn from them may surpass the Nazi Holocaust. Indeed, as the final indented quote suggests, the genocides may be even more "extreme" than Nazi genocide (in their more "massive" exterminatory impact, for example), even if the Nazis' recourse to industrialized extermination heightens their genocides' uniqueness.

${ }^{30}$ Chomsky, Turning the Tide, 39 .

${ }^{31}$ Noam Chomsky, Understanding Power: The Indispensable Chomsky, ed. Peter R. Mitchell and John Schoeffel (New York: The New Press, 2002), 135-136.

${ }^{32}$ Chomsky, The Chomsky Reader, 121. Note also Chomsky's description of Columbus as "the genocidal monster whose exploits we celebrate each October" (Chomsky, Turning the Tide, 146).

${ }^{33}$ Noam Chomsky, Deterring Democracy (London: Verso, 1991), 360.

${ }^{34}$ Chomsky, Chronicles of Dissent, 10.

${ }^{35}$ In the US context, he also notes genocidal attacks against specific indigenous nations, e.g. in his reference to "the Native American Montauketts, who were destroyed in the US genocide" (Noam Chomsky and Ilan Pappé, Gaza in Crisis: Reflections on Israel's War against the Palestinians [London: Hamish Hamilton, 2010], 33), and separately to "the first really major act of genocide in New England, the Pequot Massacre of 1637" (Chomsky, Understanding Power, 265).

${ }^{36}$ See, e.g., Chomsky's critique of the "liberal political analyst Russell Baker," whom he quotes as describing North America and Mesoamerica as "a continental vastness sparsely populated by farming and hunting people ... [in which] there may have been scarcely more than a million inhabitants." Chomsky's response is that "the calculation is off by many tens of millions, and the 'vastness' included advanced civilizations. But no matter. The exercise of genocide denial with a vengeance again merits little notice, presumably because it is so unremarkable and in a good cause." Noam Chomsky, Hopes and Prospects (London: Hamish Hamilton, 2010), 19.

${ }^{37}$ In addition to the Columbus Day references already cited, note this acid comment: "We still name our military helicopter gunships after victims of genocide. Nobody bats an eyelash about that: Blackhawk. Apache. And Comanche. If the Luftwaffe named its military helicopters Jew and Gypsy, I suppose people would notice." Noam Chomsky, Propaganda and the Public Mind (Boston: South End Press, 2001), 194. 
Of particular relevance to Chomsky's broader understanding of genocide, and to current scholarly debates over genocide and modernity, is an exchange with David Barsamian, who asked him: "Could you talk about the twentieth century nation-state? ... What is it in its makeup that permits ... genocide?" Chomsky demurred in his response:

I don't entirely [agree]. I think there's some truth to it, simply because the modern nationstate and the European model, that is, including the United States, happened to be by historical standards enormously powerful. The degree of power in the hands of a modern nation-state is something with no historical parallel. This power is centrally controlled to a very high extent with a very limited degree of popular participation in how that power is exercised. Also, we have an awesome increase in the level of power in the hands of the state, and as a result we have an enormous amount of violence. However, it's very misleading to think of, say, genocide as being a twentieth century phenomenon..$^{38}$

\section{Genocide: Secondary Cases}

A range of additional cases of "genocide" may be held to occupy a secondary tier in Chomsky's analysis, on the grounds that (1) he cites them less regularly and spontaneously than he does the Nazi and indigenous-American examples; and/or (2) the "genocide" descriptor is more likely to be quoted from other sources; and/or (3) Chomsky hedges the cases with qualifications, circumlocutions, and ambiguities/inconsistencies of terminology.

\section{Biblical Genocide}

Though he touches on this subject only in passing, Chomsky's framing of the mass violence depicted in the core Judeo-Christian texts is emphatic. "Probably the extremes of savagery recorded savagery, at least - are in the earliest histories, in the Bible," he declares in Rogue States:

I suppose that in the entire literary canon there is nothing that exalts genocide with such fervor and dedication and enthusiasm as the commandments of the warrior God to his chosen people - for example, his commandments delivered to King Saul by the prophet Samuel, who was the most just of the judges, and who conveyed the commandment to Saul to attack Amalek and spare nothing, killing all men, women, infants, and sucklings, oxen and sheep, camels and asses - the reason being that centuries earlier the Amalekites had stood in the way of the Hebrews conquering their Holy Land. Saul, as you may remember, spared one person, the king of Amalek, and some of the cattle. Samuel, when he discovered this, was enraged and cut down the captured prisoner before the Lord at Gilgal. And so the story continues. ${ }^{39}$

Likewise, in The Fateful Triangle, Chomsky cited "the genocidal texts that appear in the book of Joshua and elsewhere [in the Hebrew Bible]." ${ }^{40}$ In Imperial Ambitions, he described "massacres, like the Pequot massacre" of indigenous peoples in North America as "just like chapters out of the most genocidal parts of the Bible, which in fact the settlers quoted liberally." ${ }^{41}$

\section{The Armenian Genocide}

Without exception in my sample of dozens of his works, Chomsky's comments on the Ottoman destruction of the Armenian population occur in response to questions put to him by David Barsamian, who is of Armenian descent. Chomsky is straightforward in referring to it as "the Armenian genocide," as in an exchange printed in Stenographers to Power, and deploring "our casual attitude towards [it]." 42 Nonetheless, it is worth noting the instrumental use to which Chomsky puts this recognition: pivoting off the "genocide" to emphasize the politicization of the term and concept, and the obfuscation or outright denial of this and other genocides. "For example, I would

\footnotetext{
${ }^{39}$ Noam Chomsky, Rogue States: The Rule of Force in World Affairs (Cambridge: South End Press, 2000), 158.

${ }^{40}$ Chomsky, The Fateful Triangle, 154; see also 444.

${ }^{41}$ Noam Chomsky, Imperial Ambitions: Conversations with Noam Chomsky on the Post-9/11 World (London: Hamish Hamilton, 2005), 185.

${ }^{42}$ Barsamian, Stenographers to Power, 77-78.
} 
wager that more people are aware of the Armenian genocide during the First World War than are aware of the Indonesian genocide in 1965," he tells Barsamian in the same conversation. ${ }^{43}$

Of special relevance, for Chomsky, is Israel's longstanding refusal to recognize the Armenian genocide, and its attempts to suppress domestic discussion of it. "Israel has been very strongly opposed to efforts to bring the Armenian genocide into consideration," he tells Barsamian in Chronicles of Dissent. "The extent of this is really astonishing." ${ }^{44}$ Then there is this exchange in Power Systems:

Barsamian: And now there's a report that Israel, which has long denied the Armenian genocide, is considering a resolution condemning it, primarily to irritate the Turks, who they know are hypersensitive to any mention of the Armenian genocide.

Chomsky: It cuts both ways. Israel and Turkey were pretty close allies. In fact, Turkey was Israel's closest ally, apart from the United States. Their connection was kept under cover, but it was perfectly clear from the late 1950s on. It was very important for Israel to have a powerful non-Arab state ally. Turkey and Iran under the shah were very close to Israel. At that time, Israel refused to allow any discussion of the Armenian genocide. ... At that time, Turkey was an ally, so you didn't talk about the Armenian genocide. Now, as you say, relations are frayed, so you can sort of stick it to the Turks. You can talk about it now. ${ }^{45}$

Genocide scholars may be interested, even a little amused, to see Chomsky's multiple references in this context to his personal relationship with one of the pioneers of our field - someone who, at least in communications with me, has been harshly critical of Chomsky. As Chomsky relates to Barsamian,

In 1982, Israel Charny, somebody I knew as a kid in Hebrew camp, organized a Holocaust conference in Israel. He wanted to invite someone to talk about the Armenian atrocities, and the government tried to block it. In fact, they pressured Elie Wiesel, who was supposed to be the honorary chair, to resign. The conference organizers went ahead with it anyway, over strong government opposition. ${ }^{46}$

Note also the similar comments in World Orders, Old and New:

I keep learning new things about [Israeli opposition] all the time. For example, in 1982 there was a conference on genocide in Israel. It was organized by a childhood friend of mine. He is a psychologist there. The conference was dealing with all kinds of genocide. The Israeli government put pressure upon it to drop the Armenian genocide. They allowed the others, but not the Armenian one. The honorary chairman was to have been Elie Wiesel, and he was pressured by the government to withdraw, and being a loyal commissar as he is, he withdrew from the conference because the Israeli government had said they didn't want [the] Armenian genocide brought up. ${ }^{47}$

These intriguing references aside, we should link Chomsky's comments on this genocide to his broader critique of Israeli/Zionist manipulations of a Holocaust (Shoah) discourse, designed among other things to preserve it as a unique historical crime. This is examined in greater detail below.

With this incorporation of the Armenian and Biblical cases, I believe we have exhausted those to which Chomsky has unhesitatingly and consistently applied the "genocide" appellation. The

${ }^{43}$ Ibid., 78 .

${ }^{44}$ Chomsky, Chronicles of Dissent, 216.

${ }^{46}$ Ibid., 94.

${ }^{47}$ Noam Chomsky, World Orders, Old and New (New York: Columbia University Press, 1994), 216. A very similar account of the 1982 conference is rendered in Noam Chomsky, What We Say Goes: Conversations on US Power in a Changing World (London: Allen \& Unwin, 2007), 178. The notes to Power Systems also include two citations of Charny's published work (in one case his name is misspelled as "Charney"). 
remaining cases in this section are ones in which Chomsky has deployed a genocide framing, while sometimes offsetting a clear verdict with more qualified ones or limiting the "genocide" references to quoted passages. They still merit discussion here, though, since the ambiguities and inconsistencies are substantially less pronounced than for cases noted in the subsequent section of the article.

\section{Indonesia in 1965-66}

I have already cited Chomsky's "wager" comparing awareness of "the Armenian genocide" to that of "the Indonesian genocide of 1965." The passage continues by citing a death toll of "700,000 people ... massacred within a couple of months" (an understatement of the duration of the killing) ${ }^{48}$ Note Chomsky's comment, immediately following: "That genocide was used, including by American liberals, I should say, as justification for our war in Indochina." Notable, too, is a pair of references to the Indonesian "holocaust," in the first work that Chomsky coauthored with Edward S. Herman, the pamphlet Counter-Revolutionary Violence: Bloodbaths in Fact and Propaganda. "The [Indonesian] army played a key role in this holocaust, doing a large part of the killing directly ... and actively stimulating an anti-Communist hysteria that contributed greatly to wholesale mass murder," and "... The American response to the holocaust proper was restrained." 49

It is rare for "holocaust" to be deployed in this manner in Chomsky's sole-authored writings and spoken declarations. As with the much more extensive and substantial critique of Indonesian mass atrocities in East Timor, explored next, one suspects that the terminology reflects his coauthor Herman's preferred phrasing more than his own.

\section{East Timor}

Aside from the contemporary Cambodian case with which it is generally paired, it is possible that no other genocide or quasi-genocide receives such extensive attention and detailed exploration in Chomsky's writings as that of East Timor. Whatever reservations and furious accusations have been directed at Chomsky and his co-author, Edward S. Herman, for their treatment of genocide under the Khmer Rouge (see "Cambodia: 'Allegations of Genocide,"' below), one must acknowledge that their meticulous documentation and ringing condemnation of Indonesian atrocities in Timor were crucial in drawing activist and, eventually, mainstream attention to those crimes. This, in turn, helped to pave the way for the worldwide outpouring of protest during the final Indonesian crackdown in 1999, at the time of the UN-supervised plebiscite on Timorese independence.

Incorporating the Timorese case in our analysis is somewhat complicated by the uncertain authorship of passages in Chomsky's key coauthored work with Herman, The Washington Connection and Third World Fascism (volume one of their seminal two-volume study, The Political Economy of Human Rights). Section 3.4.4 of this book is titled "East Timor: Genocide on the Sly" 50 - the only time, to my knowledge, that "genocide" has appeared in the section heading of a work authored or coauthored by Chomsky. One senses, nonetheless, that this was more at Herman's behest than Chomsky's, given the former's demonstrably greater interest in the subject and readiness to deploy the term in some depth. (As noted, this culminated in Herman's disgracefully denialist 2010 screed, The Politics of Genocide, coauthored with David Peterson and featuring Chomsky's foreword.)

Chomsky's own verdict on Indonesian crimes in East Timor has been both equally trenchant and more varied in its language. At times, a "genocide" framing seems straightforward, as in comments quoted in Mark Achbar's Manufacturing Consent documentary companion. Media silence about atrocities in Timor, Chomsky claimed, extends

way beyond just demonstrating the subservience of the media to power. I mean, they have real complicity in genocide in this case. The reason that the atrocities can go on is because

\footnotetext{
${ }^{48}$ Barsamian, Stenographers to Power, 77-78.

${ }^{49}$ Chomsky and Herman, Counter-Revolutionary Violence, unpaginated.

${ }^{50}$ Noam Chomsky and Edward S. Herman, The Washington Connection and Third World Fascism (Boston: South End Press, 1979), 129.
} 
nobody knows about them. If anyone knew about them there would be protests and pressures to stop them. So therefore, by suppressing the facts, the media are making a major contribution to some of the - probably the worst act of genocide since the Holocaust. ${ }^{51}$

"... Genocide in East Timor [is something] we [i.e., the US] can support," Chomsky declares in Understanding Power. ${ }^{52}$ Elsewhere in the volume, which compiles spoken presentations over the years, he states: "And this is genocide, if you want to use the term, for which the United States continues to be directly responsible."53 The "if you want ..." phrasing here points again to Chomsky's ambivalence toward "genocide." I will explore some of his hesitations and reservations with regard to East Timor as an illustrative case in the section on "Quasi-Genocide," below.

\section{Guatemala}

On several occasions, Chomsky has directly applied a genocide framing to the Guatemalan genocide of the late 1970s and early 1980s. In Rogue States, he cites the UN-sponsored Historical Clarification Commission's "attribut[ion of] virtually all of the atrocities - and they are monstrous, up to genocide - to the government." ${ }^{54}$ He refers to "the genocide in Guatemala" in Understanding Power, condemning Israeli "support" for the genocide..$^{55}$ In The Fateful Triangle, and in conversation with Barsamian in Chronicles of Dissent, he again focuses on Israel's role as "a militarized dependency" of the US - "technologically advanced and ready to undertake tasks that few are willing to endure - support for Guatemalan genocide, for example" 56 or as a "dependable, reliable ally ... [who] will do what we [the US] want, like, say, support genocide in Guatemala or whatever." 57 He accused Elie Wiesel of ignoring "ongoing genocide in Guatemala, with tens of thousands of Indians slaughtered," 58 and of playing up the more politically convenient case of the Miskito Indians of Nicaragua (see further discussion in "Genocide: Politicization and Misrepresentation," below).

On other occasions, Chomsky has chosen to cite others' applications of "genocide" to this case, as when he speaks of "massacres that the conservative [Guatemalan] Church hierarchy calls 'genocide"'; 59 or to qualify his language significantly, as when he states that "Despite all the terror in Guatemala - you could even call it something like genocide - the working-class unions are reconstituting, they're still there." ${ }^{60}$ I likewise cite other examples of these qualified phrasings in the section on "QuasiGenocide."

\section{El Salvador}

As with the Guatemalan case, Chomsky has been forceful in applying a "genocide" framing to the mass atrocities of the 1980s in neighboring El Salvador. But to my knowledge, he has always done so indirectly, that is, by supportively citing commentators who use the term. An apparent exception is his comment in Necessary Illusions, noting the assumption of US "hawks and doves alike that it would have been a major crime to provide the defenseless [Salvadoran] civilian population with means to defend themselves against a war of extermination and genocide - at least, when the war is conducted by US clients, with US support and, as it reached its climax, direct organization

\footnotetext{
${ }^{51}$ Achbar, Manufacturing Consent, 116. To an extent that I think is unmatched by any other case, Chomsky has regularly attached the "worst since the Holocaust" designation to Indonesian crimes in Timor, but generally with the qualification that this judgment is merited "relative to the population" (e.g. Chomsky, Understanding Power, 295, using the term "slaughter"; see also Noam Chomsky, Powers and Prospects: Reflections on Human Nature and the Social Order (Boston: South End Press, 1996), 174, and Chomsky, Chronicles of Dissent, 261, referring to the "worst massacre ...").

${ }^{52}$ Chomsky, Understanding Power, 301.

${ }^{53}$ Ibid., 295.

${ }^{54}$ Chomsky, Rogue States, 93.

${ }^{55}$ Chomsky, Understanding Power, 5.

${ }^{56}$ Chomsky, The Fateful Triangle, 442.

${ }^{57}$ Chomsky, Chronicles of Dissent, 73.

${ }^{58}$ Chomsky, The Culture of Terrorism, 243.

${ }^{59}$ Chomsky, The Chomsky Reader, 128.

${ }^{60}$ Chomsky, Understanding Power, 105.
} 
and participation." ${ }^{61}$ However, the italicized phrase is repeated from the verdict of Salvadoran Archbishop Arturo Rivera y Damas cited in the preceding paragraph (and regularly elsewhere in Chomsky's corpus). ${ }^{62}$

Other sources deployed to buttress the genocide framing for El Salvador include the French journalist Édouard Bailby, who in Chomsky's account

gives a detailed report of massacres, brutality, mutilation, and terror on the part of the [Salvadoran] armed forces that are "a true repetition of the methods utilized by the SS during the second world war," since the Sumpul River massacre [May 1980], when "the genocide began," at times with the assistance of the Honduran army. ${ }^{63}$

- and a report from the Costa Rican journal Mesoamerica about the visit of Salvadorean president José Napoleón Duarte to Brazil, during which “Duarte's daughter broke into tears ... amidst boos and hisses by angry crowds waving signs saying 'Duarte is a murderer, a genocide"' (i.e. a génocidaire; presumably in Mesoamerica's Spanish rendering, un genocidio). ${ }^{64}$

Iraq: The Kurds, Sanctions, Fallujah

In highlighting US support for the Saddam Hussein regime in its war against Iran, during which it also inflicted mass extermination upon Iraqi Kurds, Chomsky avoided passing a personal verdict of "genocide," but supportively quoted a US government delegation that did:

An investigative team sent by the Senate Foreign Relations Committee in 1988 found "overwhelming evidence of extensive use of chemical weapons against civilians," charging that Western acquiescence in Iraqi use of such weapons against Iran had emboldened Saddam to believe - correctly - that he could use them against his own people with impunity - actually against Kurds, hardly "the people" of this tribal-based thug. The chair of the committee, Claiborne Pell, introduced the Prevention of Genocide Act of 1988, denouncing silence "while people are gassed" as "complicity," much as when "the world was silent as Hitler began a campaign that culminated in the near extermination of Europe's Jews," and warning that "we cannot be silent to genocide again."

Chomsky adopted a similar strategy, perhaps more cautiously but much more frequently, in condemning the system of sanctions imposed on the Iraqi regime and population following the Gulf War of 1990-91. As is frequently the case in his writings and interviews, his intent was often to highlight the politicization of "genocide," and the reluctance of the US in particular to apply the term to atrocities that it perpetrated or supported. Thus, in Hopes and Prospects, he cites the conclusion of the erstwhile director of the UN's Oil-for-Food program, Hans von Sponeck, "that the sanctions violated the Genocide Convention." ${ }^{\prime 66}$

"None of this can ever be mentioned, even in passing, by those who strike heroic poses about the alleged 'genocides' perpetrated by official enemies," Chomsky wrote, "while scrupulously avoiding or denying our own crimes, a form of depravity that is not unusual among sectors of educated opinion." ${ }^{67}$ Again reflecting both his readiness to cite the "genocide" charge, and his hesitation about the concept, Chomsky wrote in Middle East Illusions, "The only serious question

\footnotetext{
${ }^{61}$ Noam Chomsky, Necessary Illusions: Thought Control in Democratic Societies (Montréal: CBC Enterprises, 1989$), 201$.

${ }^{62}$ See, e.g., Noam Chomsky, On Power and Ideology: The Managua Lectures (Boston: South End Press, 1987), 81; Chomsky, How the World Works, 29.

${ }^{63}$ Chomsky, The Chomsky Reader, 341; see also the footnoted source provided, "Vicente Navarro, 'Genocide in El Salvador,' Monthly Review, April 1981."

${ }^{64}$ Chomsky, The Culture of Terrorism, 103.

${ }^{65}$ Chomsky, Rogue States, 26.

${ }^{66}$ Chomsky, Hopes and Prospects, 129. See the similar citation and phrasing in Interventions, adding that von Sponeck's "predecessor Denis Halliday, also a distinguished international diplomat, had resigned on the same grounds." Noam Chomsky, Interventions (San Francisco: City Lights Books, 2007), 60 (n. 2).

${ }^{67}$ Chomsky, Hopes and Prospects, 129.
} 
about the UN sanctions is whether they are simply terrible crimes or whether they are literally genocidal, as charged by those who have the most intimate acquaintance with the situation ..." 68

Lastly with regard to Iraq, as a scholar who has written extensively about the gender dimension of genocidal strategies, I was intrigued to come across Chomsky's comments, in Imperial Ambitions, about the siege and battle for Fallujah/Falluja following the 2003 overthrow of the Ba'thist regime and the rise of Sunni resistance to the US occupiers. "If civilians managed to flee Falluja, they were allowed out - except for men," Chomsky noted:

Men of roughly military age were turned back. That's what happened in Srebrenica in 1995. The only difference is the United States bombed the Iraqis out of the city, they didn't truck them out. Women and children were allowed to leave; men were stopped, if they were found, and sent back. They were supposed to be killed. That's universally called genocide, when the Serbs do it. When we do it, it's liberation. ${ }^{69}$

\section{Structural and Economic Violence: The "Silent Genocide"}

The bulk of Chomsky's enormous published output on political themes focuses on imperial violence in countries and regions of the Global South, most notably Latin America, the Middle East, and Southeast Asia (he has had notably little to say about Sub-Saharan Africa or South Asia). More global and structural themes have not escaped his notice, however, as is evident in his regular commentary about poverty and inequality, climate change and environmental degradation, and corporate depredations fuelled by capitalist and neoliberal ideologies.

What role has a "genocide" framing played here? Of particular relevance is Chomsky's repeated citing of a mid-1990s claim by Hiroshi Nakajima, director of the World Health Organization, that a "silent genocide" was inherent in the deaths of an estimated 11 million children annually from preventable diseases, "because the developed world lacks the will to provide the meagre resources needed to overcome" it. ${ }^{70}$ The " silent genocide' could be brought to a quick end," Chomsky argued, "if resources were directed to human needs rather than enrichment of a few."71 "We would not hesitate to describe these policies as genocidal if they were implemented by some official enemy," he added in Powers and Prospects. ${ }^{72}$

In World Orders, Old and New, Chomsky cited "chronic starvation" and declining "food consumption ... while food exports boom" in both Latin America and India, quoting allegations that this constituted "economic genocide."73 Corporate complicity in genocide is noted in the context of news media, as in this pithy exchange with David Barsamian in Power and Terror:

\footnotetext{
${ }^{68}$ Noam Chomsky, Middle East Illusions (Lanham: Rowman \& Littlefield, 2003), 200.

${ }^{69}$ Chomsky, Imperial Ambitions, 27. Lest this passage be taken as suggesting that Chomsky is sympathetic to a "genocide" framing for the Fallujah events, see the comments in his correspondence with George Monbiot, "Correspondence with Noam Chomsky," May 21, 2012, accessed March 31, 2019, https://www.monbiot.com/2012/05/21/2181/. "Take a concrete case: the murder of thousands of men and boys after women and children are allowed to flee if they can get away. I'm referring to Fallujah, different from Srebrenica in many ways, among them that in the latter case the women and children were trucked out, and in the former case the destruction and slaughter was so extreme that current studies in medical journals estimate the scale of radiation-related deaths and diseases at beyond the level of Hiroshima. I would not however call it 'genocide,' nor would you, and if the word were used, the more extreme apologists for western crimes ... would go utterly berserk." The massacre cited alongside Fallujah-Srebrenica in 1995-Chomsky called a "mass slaughter ... certainly a horror story and major crime, but to call it 'genocide' so cheapens the word as to constitute virtual Holocaust denial, in my opinion. It amazes me that intelligent people cannot see that."

${ }^{70}$ Chomsky, Powers and Prospects, 106; see also Noam Chomsky, What Uncle Sam Really Wants (Berkeley: Odonian Press, 1992), 173.

${ }^{71}$ Chomsky, How the World Works, 54.

${ }^{72}$ Chomsky, Powers and Prospects, 131. Allegations of "silent genocide" -indirect mass killing via starvation and privation - also emerged in Chomsky's denunciation of the humanitarian catastrophe in Afghanistan, as the US launched its bombing campaign against the country following the terrorist attacks of September 11, 2001. See Noam Chomsky, 9/11 (New York: Seven Stories Press, 2002), 96, repeated on 105. "Five days after 9-11, Washington demanded that Pakistan eliminate 'truck convoys that provide much of the food and other supplies to Afghanistan's civilian population,' and caused the withdrawal of aid workers along with severe reduction in food supplies, thereby leaving 'millions of Afghans ... at grave risk of starvation' - risk of what should properly have been termed 'silent genocide."' Noam Chomsky, Hegemony or Survival: America's Quest for Global Dominance (New York: Metropolitan Books, 2003), 129.

${ }^{73}$ Chomsky, World Orders, Old and New, 128.
} 
Barsamian: So what prevents something like East Timor or other issues from arising [in media coverage]? Why isn't there more dissent in the media? Is it just that people don't want to hear it, so they're not going to make money?

Chomsky: Why should a major corporation be interested in exposing the fact that they're involved in genocide?

Barsamian: They're not. It's the US government.

Chomsky: They're part of the system that runs the US government. ${ }^{74}$

Readers of Chomsky's Deterring Democracy are unlikely to forget his brilliant polemic against the global tobacco industry, which he likened to the Opium Wars of the $19^{\text {th }}$ century, with poisonous products being pushed on populations - via marketing - in the Global South. In this context, Chomsky wrote, "it might be fair to warn of the blurring of the boundary between narcotrafficking and genocide." 75

In recent years in particular, environmental destruction and anthropogenic climate change have moved to the forefront of both global concerns and Chomsky's. ${ }^{76}$ "... We are moving toward what may in fact be the ultimate genocide - the destruction of the environment," Chomsky claimed in On Western Terrorism. "And this is barely being addressed; in fact, the United States is going backwards on it."77

In light of Chomsky's anarchist political sympathies, I find a final example of (potential) structural/economic "genocide" to be especially intriguing, perhaps unexpected. In an exchange reprinted in the collection Chomsky on Anarchism, Barry Pateman asked Chomsky for his thoughts on those who argue that societies need to "step back, or forward in their eyes, to a more natural, organic world of nature. Is that possible?" Chomsky's response:

You know, I sympathize with people who say that, but I do not think that they are realizing that what they are calling for is the mass genocide of millions of people because of the way society is now structured and organized, urban life and so forth. If you eliminate these structures everybody dies. For example, I can't grow my own food. It's a nice idea, but it's not going to work, not in this world. And, in fact, none of us want to live a hunter-gatherer life. There are just too many things in life that the modern world offers us. In just plain terms of survival, what they are calling for is the worst mass genocide in human history. And, unless one thinks through these things, it's not really serious. ${ }^{78}$

\section{Cambodia: "Allegations of Genocide"}

The Cambodian genocide of $1975-78$ is certainly the most contentious and complex case in Chomsky's oeuvre, and deserves a section to itself. It underpinned the second (chronologically) of the three substantial genocide-related controversies in which Chomsky has been embroiled during his career. The first of these - the "Faurisson affair," beginning in the late 1970s - is not addressed here. ${ }^{79}$ The most recent controversy, over Herman and Peterson's The Politics of Genocide, is likewise not explored beyond a citation from Chomsky's foreword. In neither of these cases was Chomsky's presentation of the mass atrocities - in the Nazi and Rwandan genocides, respectively - at the heart of the dispute. Indeed, in the sample set of his writings consulted here, and to my knowledge outside it, Chomsky has had surprisingly little to say about either genocide as such - he has displayed greater interest in the way the Holocaust has been used for political purposes than in

\footnotetext{
${ }^{74}$ Chomsky, Power and Terror, 98-99.

${ }^{75}$ Chomsky, Deterring Democracy, 127.

${ }^{76}$ See, e.g., Chomsky's public address, "Racing to the Precipice: Global Climate, Political Climate," Starr Forum, MIT Center for International Studies, March 24, 2017, available on YouTube at https://www.youtube.com/ watch?v=TK0R 06zOOY (accessed February 9, 2020).

${ }_{77}$ Noam Chomsky and Andre Vltchek, On Western Terrorism: From Hiroshima to Drone Warfare (London: Pluto Press, 2013), 2.

${ }^{78}$ Noam Chomsky, Chomsky on Anarchism, ed. Barry Pateman (Edinburgh: AK Press, 2005), 226.

${ }^{79}$ There is a useful short summary of the "Faurisson Affair" on Wikipedia at https://en.wikipedia.org/wiki/Faurisson affair (accessed February 10, 2020).
} 
how it unfolded historically. And he has written and said virtually nothing about the 1994 genocide in Rwanda; the shocking misrepresentation of this case in The Politics of Genocide is Herman and Peterson's. (I will have a little more to say about Chomsky's cursory presentation of the Rwandan case in the section on "Genocide and Humanitarian Intervention," below.)

The Cambodian/Khmer Rouge case is notably different, in that Chomsky, mostly in work coauthored with Herman, passed judgment on both the political use and representation of Khmer Rouge atrocities, and the empirical characteristics and appropriate contextual framing of the events themselves. Some brief notes on the background are thus required before we turn to Chomsky's written and spoken declarations on the subject.

Chomsky rose to public prominence through his writings on the US attacks on Indochina in the 1960s and 1970s, and the role he played in the antiwar movement from the mid-sixties onward. In June 1977, just over two years after the Khmer Rouge vanquished the Lon Nol regime in Cambodia, seized power, and renamed the country "Democratic Kampuchea," Chomsky and Herman published an article, "Distortions at Fourth Hand," which addressed media coverage and intellectual commentary about both postwar Vietnam and Cambodia. ${ }^{80}$ The article challenged mainstream US reportage on Vietnam, contrasting it with more favorable but obscurely-published evaluations. Much of the same approach featured in the authors' treatment of Cambodia. The prevalent inattention to the country prior to the Khmer Rouge seizure of power was contrasted with the widespread allegations of mass atrocities thereafter, when "useful lessons [could] be drawn and public opinion mobilized in directions advantageous to the established order." This "didacticism," Chomsky and Herman wrote in The Nation, "often plays fast and loose with the truth."

Their review of "sharply conflicting assessments" of Khmer Rouge policies between April 1975 and early 1977 included the caveat that "We do not pretend to know where the truth lies ..." Nonetheless, they criticized the prevailing/mainstream readiness to accept as fact "evidence" that they argued was fabricated or highly dubious, and condemned "extreme anti-Khmer Rouge distortions" in, for example, John Barron and Anthony Paul's Murder in a Gentle Land: The Untold Story of Communist Genocide in Cambodia. This work, which assigned to the Khmer Rouge responsibility for over a million excess deaths during the period, they described as "a third-rate propaganda tract" featuring "scholarship [that] collapses under the barest scrutiny."

With regard to the claimed death toll in Cambodia during the first two years of Khmer Rouge rule, Chomsky and Herman assigned primary responsibility to "the enormous destruction and murder resulting directly from the American [aerial-bombing] attack on Cambodia, the starvation and epidemics as the population was driven from their countryside by American military terror and the US-incited civil war." They also cited reports running counter to the mainstream portrayal, which

concluded that executions have numbered at most in the thousands; [and] that these were localized in areas of limited Khmer Rouge influence and unusual peasant discontent, where brutal revenge killings were aggravated by the threat of starvation resulting from the American destruction and killing. These reports also emphasize both the extraordinary brutality on both sides during the civil war (provoked by the American attack) and repeated discoveries that massacre reports were false. They also testify to the extreme unreliability of refugee reports, and the need to treat them with great caution ... ${ }^{81}$

Chomsky and Herman suggested that available evidence did not support comparisons of the Khmer Rouge with the Nazis (including the claim in an April 1977 United Press International (UPI) press report that 1.2 million people "have been killed or have died as a result of the Communist regime since April 17, 1975"). A "more nearly correct" assessment, they stated, could be that "Cambodia is more similar to France after liberation, where many thousands of people were massacred within a few months under far less rigorous conditions than those left by the American

\footnotetext{
${ }^{80}$ Noam Chomsky and Edward S. Herman, "Distortions at Fourth Hand," The Nation, June 6, 1977, available online at https://chomsky.info/19770625/ (accessed February 9, 2020).

${ }^{81}$ Chomsky and Herman, Distortions at Fourth Hand.
} 
war." Evidence had been "seriously distorted," they claimed, "emphasizing alleged Khmer Rouge atrocities and downplaying or ignoring the crucial US role, direct and indirect, in the torment that Cambodia has suffered." Critiques focusing on "the American role," they wrote, were being "ignored, not on the basis of truthfulness or scholarship but because the message is unpalatable."

I quote at length from this earliest published commentary by Chomsky on Cambodia because its core themes and arguments have underpinned his references to "genocide" under the Khmer Rouge. These include:

- Skepticism toward "state-directed genocide." Writing again with Herman, in After the Cataclysm, Chomsky argued "there may be a good deal of local variation rather than the coordinated campaign of state-directed genocide that the media and their main sources prefer." 82 A "crucial element" in the prevailing propaganda portrait, they argue, is "that the Khmer Rouge leadership was committed to systematic massacre and starvation of the population it held in its grip, that is, to 'autogenocide.' It would be of little use to contemporary Western ideology if it were to be shown that peasant revenge, undisciplined troops and similar factors (still worse, the legacy of the US attack) were responsible for deaths and killings in Cambodia." ${ }^{83}$

Note also the distinctions drawn in the following two, very similar passages:

By mid-1977, according to US intelligence, the death toll [in Cambodia] had reached "tens if not hundreds of thousands," mostly from disease, malnutrition, and overwork, the result primarily of "brutal, rapid change," not "mass genocide" ...; this assessment, ignored at the time since it did not satisfy the current propaganda requirements, is now quite generally confirmed by subsequent scholarship. ${ }^{84}$

... The chorus of protest over Khmer Rouge "genocide" or "autogenocide" reached its peak of outrage in early 1977, at a time when State Department intelligence - the only source with substantial information - estimated the toll at "tens if not hundreds of thousands" from all causes, primarily "disease, malnutrition or other factors" rather than outright killing - an estimate that stands up rather well in the light of subsequent scholarship. ${ }^{85}$

We see again Chomsky's understanding that a verdict of "mass genocide" - the phrase is quoted from a US State Department source (Timothy Carney) first cited in After the Cataclysm ${ }^{86}$ - is undermined if the killing is not "outright" and monocausal, but rather indirect and multicausal.

- Highlighting the US role in perpetrating mass atrocities in the pre-1975 and Khmer Rougeera mass atrocities. On various occasions, alone or with Herman, Chomsky deploys the framing of a "decade of genocide" in Cambodia, as advanced in an issue of the journal Inside Asia. The phrase is always placed in quotation marks, as here in a 1985 article for Inside Asia, reprinted in The Chomsky Reader:

The torture of Cambodia during the "decade of genocide" is one of the horror stories of the modern period, one that is far from ended. ... The "decade of the genocide" had two phases: the 1970-75 war and the Khmer Rouge atrocities of 1975-78 (and the subsequent famine). The two are not unrelated. ${ }^{87}$

Does this constitute a "relativizing" of Khmer Rouge "genocide"? That seems to be the intent of the following comment by Chomsky during an exchange at a teach-in in Rove, Mass., in April 1989, published in Understanding Power:

\footnotetext{
${ }^{82}$ Noam Chomsky and Edward S. Herman, After the Cataclysm: Postwar Indochina and the Reconstruction of Imperial Ideology (Montréal: Black Rose Books, 1979), 145.

${ }^{83}$ Chomsky and Herman, After the Cataclysm, 185.

${ }^{84}$ Chomsky, The Chomsky Reader, 310.

${ }^{85}$ Chomsky, The Culture of Terrorism, 46.

${ }^{86}$ Chomsky and Herman, After the Cataclysm, 160.

${ }^{87}$ Chomsky, The Chomsky Reader, 289.
} 
[Unidentified] Man: But we may be heading for another genocide [if the Khmer Rouge return to power].

Chomsky: Well, look, the business about "genocide" you've got to be a little careful about. Pol Pot was obviously a major mass murderer, but it's not clear that Pol Pot killed very many more people - or even [any] more people - than the United States killed in Cambodia in the first half of the 1970s. We only talk about "genocide" when other people do the killing. ... If we were honest about the term "genocide," we would divide up the deaths in the Pol Pot period into a major part which is our responsibility, which is the responsibility of the United States. ${ }^{88}$

- Uncertainty of the death toll and unreliability of estimates. In Manufacturing Consent, Herman and Chomsky contend that "the actual scale of the slaughter and destruction during the two authentic phases of large-scale killings during the 'decade of the genocide' (phases I and II [i.e. 1970-78]) would be difficult to estimate at best, and the problems have been compounded by a virtual orgy of falsification serving political ends that are all too obvious." Estimates by the Finnish Commission of Inquiry and by the scholar Michael Vickery, they argue, "suggest that the toll under phase II of 'the genocide' [under the Khmer Rouge] is somewhat greater than that under phase I [the American war], although not radically different in scale. But before accepting these figures at face value we must bear in mind that part of the death toll under phase II must be attributed to the conditions left by the US war." 89

In this context, Chomsky has regularly cited an order by Henry Kissinger "to the Pentagon to carry out a 'massive bombing campaign in Cambodia. Anything that flies on anything that moves.' That is the most explicit call for what we call genocide when other people do it that I've ever seen in the historical record." ${ }^{\prime 90}$ In a 2010 interview published in The Phnom Penh Post, Chomsky describes it as having "clear genocidal intent." Chomsky declare in Manufacturing Consent, is notably not "designated a period of 'holocaust' or 'genocide' in mainstream literature. Phase I elicited no calls for international intervention or trials for crimes against humanity, and it has since been largely expunged from the record." 92

In summary, Chomsky has (1) devoted greater critical attention to the validity of a "genocide" framing for Cambodia than for any other case or alleged case of genocide; (2) challenged the application of a "genocide" framing to the Khmer Rouge period, at least the 1975-77 period; and (3) stressed the need to include the United States among the culprits of mass atrocity. One senses, however, a certain evolution in his writing and speaking on the subject over the years. For example, his citing of "subsequent scholarship" in the two indented passages immediately above reflects the state of research as of the later 1980s. A great deal has appeared since, and Chomsky, perhaps grudgingly, seems to have grown more forthright in his terminology, for example in referring to "Pol Pot's genocide" $\mathrm{He}$ has also spoken in straightforward support of trials of Khmer Rouge perpetrators, while expressing a preference that the proceedings be "left to the Cambodian people" and incorporate

\footnotetext{
${ }^{88}$ Chomsky, Understanding Power, 92-93.

${ }^{89}$ Edward S. Herman and Noam Chomsky, Manufacturing Consent: The Political Economy of the Mass Media (New York: Pantheon Books, 1988), 263.

${ }^{90}$ Chomsky, Imperial Ambitions, 100.

${ }^{91}$ Stuart Alan Becker, "Noam Chomsky Maintains the Rage," The Phnom Penh Post, October 5, 2010, available online at https://www.phnompenhpost.com/national/noam-chomsky-maintains-rage (accessed February 9, 2020).

${ }^{92}$ Herman and Chomsky, Manufacturing Consent, 262.

${ }_{93}$ Chomsky, What We Say Goes, 103.

${ }^{94}$ Chomsky, Interventions, 204. There is also this in the Manufacturing Consent documentary companion, published in 1994; the date of the statement, made at the Massachusetts Institute of Technology, is uncertain: "I mean the great act of genocide in the modern period is Pol Pot, 1975 through 1978 - that atrocity - I think it would be hard to find any example of a comparable outrage and outpouring of fury and so on and so forth." I think, however, the appropriate reading of this passage would be: "the great act of genocide in the modern period is [taken to belusually cited as] Pol Pot ..." Achbar, ed., Manufacturing Consent, 95.
} 
US crimes. ${ }^{95}$ The trajectory bears a limited comparison with that of Ben Kiernan, the leading scholar of the genocide, who acknowledged that he was initially "sympathetic to [the Khmer Rouge's] purported reforms and nationalism," but in 1979 issued a formal retraction. ${ }^{96}$ Chomsky, however in his political writings at least - does not "do" formal retractions, to my knowledge.

\section{Quasi-Genocide}

I use this term to encompass a range of vocabulary that Chomsky has employed to suggest that certain severe atrocities fall somewhat short of genocide. These qualifications provide further evidence of Chomsky's "hard" understanding of genocide, as explored at the outset of this essay. That is, for the threshold to be crossed in his framing, the atrocities should be fully exterminatory or nearly so, direct rather than indirect, and centrally planned - mirroring Nazi genocide in particular. As well, the phrasings here buttress the earlier contention that despite his hesitations and reservations about the "genocide" label, Chomsky has regularly sought to activate its special rhetorical and political power, to provoke concern and convey the seriousness and severity of the atrocities in question.

- "Near-genocide." In How the World Works, Chomsky describes "positively ecstatic" US support for "near-genocide in Guatemala" during the 1980s. ${ }^{97}$

- "Virtual genocide." According to Chomsky, Andrew Jackson's proclamation of the Indian Removal Act "set off a virtual genocide" of Native nations in the southern US. ${ }^{98}$ He also accuses Italy under Mussolini of "carrying out virtual genocide" in Libya. ${ }^{99}$ In Guatemala "during Reagan's terrorist wars of the 1980s," he asserted that "one of the world's most brutal and vicious regimes ... extended its criminality to virtual genocide in the highlands." ${ }^{100}$ In Year 501, a further qualification is added: the policies of the 1980s "approached virtual genocide."101

- "Approach [ing] genocide." In his earliest collection of political essays, American Power and the New Mandarins, Chomsky quotes supportively a "letter in Science magazine [stating]: 'There can be no doubt that the DOD [US Department of Defense] is, in the short run, going beyond mere genocide to biocide." 102 Two pages later, he comments sardonically: "If it is necessary to approach genocide in Vietnam ... then this is the price we must pay in defense of freedom and the rights of man." ${ }^{103}$ With regard to Bosnia, Chomsky likewise declared at the time that "the slaughter is approaching genocide." 104

- "Genocidal" vs. "genocide." Chomsky sometimes employs the construction of "genocidal $X$ " in preference to "genocide," in which the $X$ is a further qualifier: "activities," "assaults," "method[s]." Somewhat speculatively, I venture that this reflects his understanding of genocide as a fully or nearly fully consummated enterprise, and his reservations about using the term. Thus he

\footnotetext{
${ }^{95}$ George McLeod, “Tribunal Ignoring US Role, Says Chomsky," The Phnom Penh Post, March 27, 2009, available online at https://www.phnompenhpost.com/national/tribunal-ignoring-us-role-says-chomsky (accessed February 9, 2020). In the 2010 Phnom Penh Post interview previously cited (see note 91), Chomsky states: "I am opposed to the death penalty, but I think they [Khmer Rouge perpetrators] should receive fair trials and imprisonment. No one asks that question about Nixon and Kissinger, or about the rich and powerful generally."

${ }^{96}$ See the discussion in a useful undergraduate thesis by Breanna Atwood, "Khmer Rouge: Evolution of the Academic Debate," March 12, 2010, accessed February 9, 2020, available online at http://digitalcommons.calpoly.edu/cgi/ viewcontent.cgi? article $=1004 \&$ context=histsp.

${ }^{97}$ Chomsky, How the World Works, 38. The identical passage appears in Chomsky, On Power and Ideology, 30, and in Chomsky, What Uncle Sam Really Wants, 49.

${ }^{98}$ Noam Chomsky, Keeping the Rabble in Line (Monroe: Common Courage Press, 1994), 77.

${ }^{99}$ Afterword to Failed States, reprinted in Noam Chomsky, The Essential Chomsky, ed. Anthony Arnove (New York: The New Press, 2008), 404. The same assessment is found in Making the Future: “... After World War I, Italy conducted virtual genocide in eastern Libya." Noam Chomsky, Making the Future: Occupations, Interventions, Empire and Resistance (San Francisco: City Lights Books, 2012), 267.

${ }^{100}$ Chomsky, Hopes and Prospects, 105. Chomsky has also quoted Guatemalan journalist Julio Godoy's reference to "a virtual genocide that has taken more than 150,000 victims," e.g. in Chomsky, How the World Works, 39.

${ }^{101}$ Chomsky, Year 501, 28-29.

102 Noam Chomsky, American Power and the New Mandarins (New York: Pantheon Books, 1969), 321.

${ }^{103}$ Chomsky, American Power and the New Mandarins, 353.

${ }^{104}$ Chomsky, World Orders, Old and New, 25.
} 
refers to "the genocidal activities" of Washington's allies in Guatemala, ${ }^{105}$ and in the same volume describes "the long-suffering Mayans" as "subjected to near-genocidal assaults"106 (see also the references to "the genocidal uses to which the military aid was put" and "genocidal acts"). ${ }^{107}$ In collaboration with Edward Herman, he describes US policy in Indochina as "from the beginning semi-genocidal in purpose and method, resting in large part on the fact that the civilian population has been regarded as enemy or, at best, of no account." 108

To see these reservations and hesitations at play in his treatment of a particular case, consider again Chomsky's pronouncements on East Timor. In conversation with David Barsamian, Chomsky's verdict is both straightforward and slightly hedged, moving from "genocide" to "genocidal" to "near-genocidal":

Barsamian: You talk extensively about the events in 1965 in Indonesia and then the events in 1975, in East Timor ...

Chomsky: Which are still going on, incidentally. There's a case of genocide that's going on right today and is continuing precisely because the United States supports it. That's what blocks any possible termination of that genocidal attack.... It's quite improper for people in the United States to know that their own government is involved in a genocidal massacre which is quite comparable to Pol Pot... That whole near-genocidal attack, the term is not exaggerated in this case, was almost entirely suppressed for over four years. Even today it's barely discussed, and when it is discussed, the American role is suppressed. ${ }^{109}$

In Understanding Power, Chomsky similarly alternates "genocide," "genocidal," and "virtually genocidal"; 110 "virtual genocide" is referenced in Year 501. "111 In Towards a New Cold War, some of his earliest writing on East Timor, he cited "actions that verge on genocide."112 In The Washington Connection, he and Herman report that "the massacre advanced to a point that some feel amounts to genocide." 113 The same text includes mentions of "impending genocide" (referencing the concerns of Timorese Catholic priests), and "possible genocide."114

\section{"Prelude to Genocide"}

We have seen that on occasion, Chomsky has warned of possibly impending genocide - notably in the context of environmental destruction; his warnings about nuclear "holocaust" (see note 133) can also be noted in this regard. These are global issues. But in one case that has featured in his writings since the early 1970s - Israeli policies in the occupied Palestinian territories - Chomsky again employs the strategy of quoting another authority's use of the "genocide" term. In the Gaza Strip, Chomsky asserted in an interview for Gaza in Crisis, the US and Israel "now have a pretext for tightening the stranglehold on the people of Gaza, cheerfully pursuing policies that the prominent

${ }^{105}$ Chomsky, Turning the Tide, 33.

${ }^{106}$ Ibid., 165.

${ }^{107}$ Ibid., 35-36.

${ }^{108}$ Chomsky and Herman, The Washington Connection, 312.

${ }^{109}$ Barsamian, Stenographers to Power, 79.

${ }^{110}$ Chomsky, Understanding Power, 297.

${ }^{111}$ Chomsky, Year 501, 99.

${ }^{112}$ Reprinted in Chomsky, The Essential Chomsky, 195.

${ }^{113}$ Chomsky and Herman, The Washington Connection, 157.

${ }^{114}$ Chomsky and Herman, The Washington Connection, 195, 201. Comparable qualifications are employed in The Common Good, where Chomsky refers to "the nearly genocidal [Indonesian] campaign of 1978." Noam Chomsky, The Common Good (Tucson: Odonian Press, 1998), 98. The same 1978 campaign indicated that the violence "was approaching really genocidal levels," with an estimated 200,000 Timorese killed (Achbar, ed., Manufacturing Consent, 102); it was "really near genocide," according to another public statement cited in the same volume (154-155). "... If it was near genocide, well, things happen," he notes sardonically in On Western Terrorism; indeed, it was "as close to genocide as anything that happened" in the postwar period (Chomsky, On Western Terrorism, 145, 144). "Near-genocidal" is likewise the preferred usage in Chomsky, Deterring Democracy, 188. 
international law scholar Richard Falk describes as a prelude to genocide that 'should remind the world of the famous post-Nazi pledge of never again."'"115 In Making the Future, Chomsky again quotes Falk's accusation that "to persist with such an approach under present circumstances is indeed genocidal, and risks destroying an entire Palestinian [Gazan] community that is an integral part of an ethnic whole"116 - the only oblique reference I have seen in Chomsky's work to the "in whole or in part" language of the UN Genocide Convention.

\section{Genocide: Politicization and Misrepresentation}

The extended discussion of Cambodia, above, made it clear that Chomsky often explores a "genocide" framing in the context of perceived distortions and cynical misapplications of the term by US leaders and commentators. Its discursive power, in such cases, is co-opted to serve an imperial political agenda.

- Nicaragua/The Miskito Indians. In the early 1980s, the new Sandinista government of Nicaragua undertook repressive measures, including localized atrocities, against Miskito Indians on the country's Atlantic coast, some of whom had taken up arms with Contra forces mobilized and armed by the CIA. In June 1985, President Reagan (Chomsky writes) "chimed in with the news that the Sandinistas are conducting a 'campaign of virtual genocide against the Miskito Indians."' There were "major atrocities, no doubt," Chomsky states, "but [they were] undetectable in the context of the behavior of the United States and its clients in the region." 117 He scornfully notes that "Elie Wiesel flew down to witness their plight and evoke the conscience of the nation over it; in contrast, the revered moralist and Nobel Peace Prize laureate found himself unable to manage even a private communication to the government of Israel to ask that they cease their contribution to ongoing genocide in Guatemala, with tens of thousands of Indians slaughtered."118 Elsewhere, Chomsky, quoting the Council on Hemispheric Affairs, declares the accusations against the Sandinistas to be part of "a steady stream of calumny directed at Managua, charging the ruling Sandinistas with everything vile: drugrunning, genocide, subverting their neighbors, and now international terrorism." The charges, Chomsky notes, "have not 'been burdened with evidence' [again quoting the Council], but are reported with only rare attempts at evaluation."119

- Another example of politicized accusation, according to Chomsky, centers on the claims issued by supporters of Israel to fend off criticisms of the state's policies. "Since the Six-Day War, critics of one or another aspect of Israeli policy have been subjected to ridiculous accusations and childish distortion. They have been portrayed as supporters of terrorism or even genocide, or as opponents of democracy." "To deal seriously with the issues was not easy," he writes later in the same text. "It was much more convenient to denounce one's enemies as totalitarians, radical-chic suburbanites, anti-Semites, or backers of Arab genocide." 120

- During the 1990s, while striking a faintly accommodating stance toward claims of genocide in Bosnia (see note 12), Chomsky ridiculed them in the case of Kosovo, arguing that they were spuriously advanced in order to justify "humanitarian" (actually, he claimed, imperial) intervention in the territory. To the assertion by Timothy Garton Ash that the Kosovo intervention of 1999 was "'absolutely right,' because it passed the 'very high ... threshold for such humanitarian intervention, .... Something approaching genocide, by the killing or "ethnic cleansing" of large numbers of its people' by the Serbian government," Chomsky responded mockingly: "Surely this establishes the

\footnotetext{
${ }^{115}$ Chomsky and Pappé, Gaza in Crisis, 7. Gaza in Crisis consists of interwoven contributions from both Chomsky and Israeli scholar Ilan Pappé. Included in Pappé's commentary is a detailed consideration of whether Israeli policy toward Gaza constitutes “A Genocidal Policy?" (section heading, 191). Likewise, the volume On Palestine, also coauthored by the pair, features a chapter titled "A Brief History of Israel's Incremental Genocide [in Gaza]," with regular references to the italicized concept (Noam Chomsky and Ilan Pappé, On Palestine [Chicago: Haymarket Books, 2015]). This is again exclusively Pappé's work, though it is notable that Chomsky (a) validates the usage, to a degree, by participating in the joint projects, and (b) does not directly contest Pappé's designation and conceptual framing.

${ }^{116}$ Chomsky, Making the Future, 33.

${ }^{117}$ Chomsky, The Chomsky Reader, 354.

${ }^{118}$ Chomsky, The Culture of Terrorism, 243.

${ }^{119}$ Chomsky, Turning the Tide, 78.

${ }^{120}$ Chomsky, Middle East Illusions, 110, 133. Both quotes were originally published in Peace in the Middle East? (1974).
} 
case and justifies the praise for the altruistic leaders opening a new era of enlightenment. And so it might, if the claims had any relation to the facts." 121 In A New Generation Draws the Line, he cited and lauded "a rare exception" in media coverage, The Wall Street Journal,

which devoted its lead story on December 31 to an in-depth analysis of what had taken place. The headline reads: "War in Kosovo Was Cruel, Bitter, Savage; Genocide It Wasn't." The conclusion contrasts rather sharply with wartime propaganda. A database search of references to "genocide" in Kosovo for the first week of bombing alone was interrupted when it reached its limit of 1,000 documents. Hysterical exaggeration of the enemy's unfathomable evil is a classic feature of propaganda, particularly when it is recognized, at some level of awareness, that the case for resort to force is weak. ${ }^{122}$

- Perhaps this is also the place to note Chomsky's commentary on Darfur, likely the case that has attracted the greatest attention in the genocide-prevention community since the turn of the millennium. Prompted on the subject by David Barsamian, Chomsky responded ambivalently, but in ways that highlight the utility and convenience of the accusations for the political and intellectual powers-that-be:

... Darfur is a big issue in the United States and the West now, and a very convenient one. It's convenient because there are major atrocities undoubtedly being carried out by an official enemy. You can attribute the atrocities to Arabs, so it's perfect. Just the kind of atrocities we love. Of course, there are no serious proposals to do anything about them. ... It's also a complicated issue, not simply an issue of evil Arabs, a terrible tyrant carrying out genocide, the sort of standard story here, which has some element of truth to it but is by no means the whole story. ${ }^{123}$

In keeping with these skeptical and critical assessments are Chomsky's statements in probably the most extended genocide-specific commentary he has published, and to my mind the most noteworthy. I refer to his relatively recent (2010) foreword to Herman and Peterson's The Politics of Genocide. Here Chomsky decries "the vulgar politicization of the concept of genocide," and links it to the "emerging international norm" - Condoleeza Rice's words - of military intervention on "humanitarian" grounds. Both the "vulgar politicization" and the "emerging ... norm," Chomsky writes, "appear to be products of the fading of the Cold War, which removed the standard pretexts for intervention while leaving intact the institutional and ideological framework for its regular practice ..." 124 The norm is exclusively the province of "the traditional imperial powers," he contends, something "that should hardly come as much of a surprise." He then concludes the foreword with a sentence that merits printing in bold type:

As for the term "genocide," perhaps the most honorable course would be to expunge it from the vocabulary until the day, if it ever comes, when honesty and integrity can become an "emerging norm." 125

\footnotetext{
${ }^{121}$ Chomsky, Hegemony or Survival, 55.

${ }^{122}$ Chomsky, A New Generation Draws the Line, 94-95. See also this from the excerpt on "Imperial Grand Strategy" in The Essential Chomsky: "By now, the only way to attack a much weaker enemy is to construct a propaganda offensive depicting it as an imminent threat or perhaps engaged in genocide, with confidence that the military campaign will scarcely resemble an actual war." Chomsky, The Essential Chomsky, 395.

${ }^{123}$ Chomsky, What We Say Goes, 181. For a rare moment of comic relief, we might also cite Chomsky's reference to an imagined invasion of the US by United Nations forces in league with space aliens. The US "is very disturbed," he noted in Understanding Power: "There's complete disaffection about everything. People don't trust anyone ... And when you talk about the mood of people - well, whether it's on right-wing talk radio, or among students, or just among the general population, you get a very good reception these days for the kinds of things I talk about. But it's scary - because if you came and told people, '[President] Clinton's organizing a UN army with aliens to come and carry out genocide, you'd better go to the hills,' you'd get the same favorable response. That's the problem ..." Chomsky, Understanding Power, 396.

${ }^{124}$ Chomsky, foreword to The Politics of Genocide, 10-11.

${ }^{125}$ Ibid., 12.
} 
There could hardly be a more distilled articulation of Chomsky's deep distrust of the "genocide" concept than this call to "expunge" it from contemporary political discourse. And yet, we have seen throughout this article that Chomsky has regularly deployed the term, albeit often in quoted or qualified form, to bolster the political and polemical force of his own critique. Does the verdict rendered in the Politics of Genocide foreword indicate that he is abandoning it as too hopelessly compromised for further use?

\section{Genocide and Humanitarian Intervention}

The preceding discussion may suggest that Chomsky considers military interventions on "humanitarian" grounds to be ruled out by their inherently imperial character. This does not quite do justice to his pronouncements on the subject, however. Consider the following arguments, in which what is not said, or is implicit, is as interesting as what is stated outright.

- Impunity vs. principle. In discussing the 1999 US bombing of Kosovo in On Western Terrorism, Chomsky noted

the trial where Yugoslavia brought a case against NATO for the bombing to the International Court of Justice ... the United States excluded itself from the case and the Tribunal agreed because one of the charges mentioned was that it was a genocide, and when the United States signed the Genocide Convention after 40 years, it had a reservation saying it was 'inapplicable to the United States,' and so therefore the Court rightly excused the United States from prosecution.

For Chomsky, this shows "there are literally legal barriers established just in case anyone dares to try to bring some charge against the powerful."126 This does not constitute a judgment on military interventions in genocide and other mass atrocities, however - rather on the hypocrisy and impunity that govern those interventions.

In Power and Terror, Chomsky delivered some of his few recorded comments on the Rwandan genocide. He was responding to a questioner at the Berkeley Community Theatre in March 2002, who described attending a talk by General Roméo Dallaire, in which the leader of the UN's "Blue Helmets" in Rwanda recounted "how frustrated he was to watch genocide happen all around him when no one seemed to care, none of the world powers seemed to be doing anything. And his basic conclusion was that to him the world was just inherently a racist place ..." Chomsky responded:

First of all, I don't think what happened was racism, particularly. It's just that this didn't matter much. Remember, he was talking about what happened in Rwanda in 1994, but that's been going on in Burundi and Rwanda for years. Ed Herman and I wrote a book more than twenty-three years ago in which we discussed the Hutu/Tutsi atrocities in Burundi and Rwanda, in which hundreds of thousands of people were killed. Nobody cared then, and nobody cares now. Just like in the last two or three years, probably several million people have been killed in the Congo, and it doesn't really matter, it doesn't affect Western interests, so you don't try to do anything about it.

But they can be any color, any religion, it doesn't really matter. The principle is, does it affect US interests? ... [Dallaire is] talking about something bad, namely our unwillingness to do anything to stop atrocities. But much worse than that, incomparably worse, is our willingness to participate in atrocities. It would have been much worse if we had not only done nothing about that, but in fact had gone ahead and continued to put the guns in the hands of the murderers as they were committing murder.

I'd be a little cautious. The kind of statement he's making is correct, but that's the kind that's tolerable. So, for example, if you take a look at the New York Review of Books this week, there's a passionate article by the executive director of the Carr Center for Human Rights Policy at Harvard's Kennedy School of Government, Samantha Power, which discusses our tragic failure to pay attention to atrocities that other people are committing and to do something about them. It's some profound flaw in our character. Okay, it's a problem. But a

${ }^{126}$ Chomsky, On Western Terrorism, 27. 
much more serious problem, orders of magnitude more serious - which is not mentioned in the article and which would be unintelligible if it were mentioned - is the fact that we pay very close attention to atrocities and intervene to escalate them, and often even applaud them. ... Yeah, it's bad to overlook the crimes that are committed by others and not to do enough about them, but it's far more important to look into the mirror and look at what you're doing yourself and do something about that. So I kind of agree with Dallaire. It seems to me a bad problem, but small on the scale of moral responsibilities or human consequences. ${ }^{127}$

Note first the frankly flippant and misleading reference to "the Hutu/Tutsi atrocities in Burundi and Rwanda" that have "been going on for years," as ostensibly described in Chomsky and Herman's book The Washington Connection and Third World Fascism. Section 3.4.2 of that volume, all of two pages long, addresses Burundi and alleged US complicity in the 1972 genocide of Hutus by the Tutsi regime. "Rwanda" does not appear in the section, or elsewhere in the book.

Relevant is Chomsky's contrasting of failure to intervene in mass atrocities with complicity in the perpetration and "escalat[ion]" of mass atrocities. One can contest the claim that withholding intervention is "orders of magnitude more serious" than direct perpetration. But Chomsky's acknowledgments here - that Dallaire's critique is at least partially "correct" and attests to "a bad problem"; that "it's bad to overlook the crimes that are committed by others and not to do enough about them" - render somewhat more complicated his thinking about the so-called "Responsibility to Protect" (R2P) and "Will to Intervene" (W2I).

The picture is complicated further when we consult Chomsky's rather nuanced article on "Humanitarian Intervention" for the Boston Review. There, he argued that "a rational person will recognize that policy flows from institutions, institutions remain stable, and thus intervention is likely to be undertaken, when deemed necessary, for much the same reasons as before" - that is, for reasons of national self-interest. He urged proponents of intervention to recognize that "the leader of such intervention [i.e. the United States] will be a state that is remarkable not only for its violence, impudence, and moral cowardice, but also for its lawlessness, not only in recent years." He nonetheless offered a qualification: that "intervention undertaken on the normal grounds of power interests might, by accident, be helpful to the targeted population. Such examples exist. The most obvious recent one is Vietnam's invasion of Cambodia in December 1978 after years of murderous Khmer Rouge attacks on Vietnamese border areas ..." He also pointed to "the protection zone that the Bush Administration reluctantly extended to the Kurds in northern Iraq, after tacitly supporting Saddam Hussein as he crushed the Shiite and Kurdish uprisings. Here, public opinion played a decisive role, overcoming the Administration's commitment to the rule of a unified Iraq by an 'iron fist,' whether wielded by Saddam or some clone ..." He ended by asking whether

the conclusions that a rational observer will draw about US-led 'humanitarian intervention' do not answer the question whether such intervention should nevertheless be undertaken. That is a separate matter, to be faced without illusions about our unique nobility. We can, in short, ask whether the pursuit of self-interest might happen to benefit others in particular cases, or whether unremitting public pressure might overcome the demands of the 'principal architects' of policy and the interests they serve. ${ }^{128}$

- Available alternatives. In the following comments from Rogue States about Kosovo, and the supposed unavoidability of the 1999 military intervention, Chomsky's focus is not on military interventions as such, but the cynically politicized manner in which the presumed option-set is reduced to them:

A standard argument is that we had to do something: we could not simply stand by as atrocities continued. The argument is so absurd that it is rather surprising to hear it voiced. Suppose you see a crime in the streets, and feel that you can't just stand by silently, so you

\footnotetext{
${ }^{127}$ Chomsky, Power and Terror, 106-108.

${ }^{128}$ Noam Chomsky, “Humanitarian Intervention,” Boston Review, 18 (December 1993-January 1994), 3-6, available online at http://bostonreview.net/archives/BR18.6/chomsky.html (accessed February 9, 2020).
} 
pick up an assault rifle and kill everyone involved: criminal, victim, bystanders. Are we to understand that to be the rational and moral response?

One choice, always available, is to follow the Hippocratic principle: "First, do no harm." If you can think of no way to adhere to that elementary principle, then do nothing; at least that is preferable to causing harm. But there are always other ways that can be considered. Diplomacy and negotiations are never at an end. ... ${ }^{129}$

To pursue Chomsky's analogy, one option in confronting a serious crime in progress - let us say an attempted murder - would indeed be to use a weapon to kill or incapacitate the criminal alone. Nothing in Chomsky's call for consideration of the full range of options would necessarily rule this out.

- Moral obligations. I have never forgotten one of Chomsky's arguments during the Central American wars and genocides of the 1980s - the spur for my own earliest political activism, and for my initial encounter with Chomsky's work. Addressing US government and media allegations of support by Nicaragua's Sandinista government for the leftist rebels in El Salvador, Chomsky opined: "Everybody should be sending arms [to the rebels] ... It's perfectly legitimate to send arms to people who finally try to use violence in self-defense against a gang of mass murderers installed by a foreign power." 130 The argument is also implicit in the following passage from an appendix to Necessary Illusions. Chomsky first contested whether largescale arms shipments from Nicaragua across the Gulf of Fonseca to El Salvador were conceivable, given that the Gulf "is thirty kilometers wide, heavily patrolled by US naval vessels and SEAL teams and covered by a radar facility on Tiger Island in the Gulf that is able to locate and track boats not only in that area but far beyond." But he then turned the question on its head, declaring it "interesting" that

it is taken for granted by hawks and doves alike that it would have been a major crime to provide the defenseless civilian population [of El Salvador] with means to defend themselves against $a$ war of extermination and genocide [again referencing the comments by Archbishop Rivera y Damas, cited earlier] - at least, when the war is conducted by US clients, with US support and, as it reached its climax, direct organization and participation. To have provided victims of Pol Pot with arms to defend themselves, had this been possible, would have been considered a sign of true nobility. It is enlightening that such simple observations as these, and their obvious import, are next to unintelligible. ${ }^{131}$

Likewise, in addressing the UN-sanctioned, Australian-led military intervention in East Timor in September 1999, Chomsky hardly denounces it as an imperialist aggression cloaked in "humanitarian" guise, à la Kosovo. Instead, he limits himself to pointing out how rapidly the Indonesian military shifted from supporting atrocities to permitting the intervention, once the Clinton administration delivered a threat to cut off American military aid. Once again, more pertinent than what he says is what he does not say. He does not criticize the motives of the intervening actors and forces, but limits himself to noting the relative ease with which the intervention was brought about by a simple shift in US policy towards Indonesia's military power-wielders. It is notable, perhaps, that in the Timor case, the US did not lead the military intervention itself, and that its own interventionist strategy was limited to the threat of a cutoff in military support (viz. the alternative strategies discussed above).

Note also the unexpected tone of the following comments regarding Somalia and Bosnia, in the 1996 book Power and Prospects:

President Clinton agrees that the US must lower its contributions to UN peacekeeping operations while his right-wing adversaries want to go much further, shackling or even ending them. In contrast, they are favoured by over 80 per cent of the public. Half consistently

\footnotetext{
${ }^{129}$ Chomsky, Rogue States, 48.

${ }^{130}$ Noam Chomsky, talk at the University of California, Berkeley, May 14, 1984, http://en.wikiquote.org/wiki/Noam Chomsky (accessed February 10, 2020).

${ }^{131}$ Chomsky, Necessary Illusions, 201.
} 
support US participation, 88 per cent if there are fair prospects of success. Only 5-10 per cent consistently oppose such operations, the remainder varying with circumstances. The effect of fatalities in Somalia [on respondents] was slight, contrary to much pretence. Two-thirds favour contributing US troops to a UN operation to protect "safe havens" or to stop atrocities in Bosnia; 80 per cent take the same position with regard to Rwanda, if the UN were to conclude that genocide is underway. Nevertheless, 60 per cent of the population think the US has "done enough to stop the war in Bosnia" - namely, nothing. ${ }^{132}$

Chomsky here appears to be on the side of the US public that favors UN peacekeeping operations - certainly a form of humanitarian, indeed military, intervention - and supports the involvement of US troops in such operations to suppress "genocide." His critique is instead directed against the US for having done "nothing" to stop the Bosnian war. An intriguing contrast seems evident with his post-Kosovo and post-9/11 stances.

\section{The Holocaust: Memory and Propaganda}

We saw near the outset of this article that the Nazi genocide is one of two "paradigmatic" genocides in Chomsky's framings. I also noted that Chomsky has stressed the Roma/Gypsy dimension of the Nazis' extermination campaigns, together with (unspecified) other targets. The systematic, direct, industrialized element of the death camps makes this genocide unique, in Chomsky's understanding - but this falls short of an argument for Holocaust (i.e. Shoah) uniqueness.

I have also shown, in considering Chomsky's statements about the Armenian genocide, that he is attentive to the alleged politicization and manipulation of Holocaust memory. ${ }^{133}$ This guides his commentary on the Jewish Holocaust - rather more than do the events and atrocities of the Holocaust themselves. With regard to the Roma specifically, Chomsky in a discussion with David Barsamian cites an article from the American Jewish Congress Weekly ("a pretty liberal part of the Jewish community") by "some guy named Edward Alexander, from Americans for a Safe Israel, quasi-[Meir] Kahane, right-wing nuts," whom he likens to deniers of the Shoah:

He simply had a phrase: The Nazi genocide of the gypsies is an "exploded fiction." These gypsy stories are just fairy tales. That's exactly like the people who say the Nazis never did anything to the Jews. It's just fairy tales. If people say that about the Jews, we react with contempt, but if you say it about the gypsies, it's just fine, because who cares about them anyhow? I don't know much about him, but I suspect the motive there is to monopolize the Nazi genocide [i.e. limit it conceptually to the Shoah] because you can use it as a weapon for Israel. People like Elie Wiesel go along with this all the time. That shows us how much they actually care about the Holocaust. ${ }^{134}$

${ }^{132}$ Chomsky, Power and Prospects, 107.

${ }^{133}$ In doing so, Chomsky has also deployed the language of (generic) "holocaust" as well as "genocide" to reference the Armenian case, as in this passage: "Why are they [Israeli officials] so fixated on denying the Armenian holocaust? That's very simple. Part of it is that they want to monopolize the image for their own purposes, but the other part of it is that this is the Armenians. They were massacred by the Turks. The Turks are allies, and you don't want to alienate allies, because that's much too important. So, if they happened to carry out a genocide, that's not our business. They're our allies. Therefore, you don't talk about the Armenian holocaust." Chomsky, Chronicles of Dissent, 216. I have also found references to (small-h) "holocaust" in references to East Timor (with Herman; see above), and once (uncontroversially) to a possible "nuclear holocaust" (American Power and the New Mandarins, reprinted in Chomsky, The Essential Chomsky, 72).

${ }^{134}$ Chomsky, Chronicles of Dissent, 217. I have not been able to locate a link to Alexander's original article. In the same discussion, Chomsky connects the cited Alexander comment to the controversy surrounding "the Faurisson affair," in which a statement of his, defending the right of that gas-chamber denier to publish his views freely, was used by his (Chomsky's) French publisher as the preface to "a book in which Faurisson defends himself against the charges soon to be brought against him in court" (see Chomsky, "His Right to Say It"). For Chomsky, this was a simple matter of defense of civil liberties, at a time when Faurisson, for his denialist declarations, was the subject of legal proceedings by the French state: "... Just as I support the right of American war criminals to teach in American universities, even at the time when their research is being used for war crimes, I support the right of people to say whatever horrendous thing they like, even if one doesn't like it. So for example, if the Journal of the American Jewish Congress publishes, as it recently did, an article claiming that the Nazi genocide of the gypsies is an exploded fiction, I don't say that the American Jewish Congress's editors should be brought to court for Nazi apologetics and for denying an act of 
Overseas Jewish organizations such as the Anti-Defamation League of B'nai B'rith, he alleges, "don't ultimately care about anti-Semitism, what they care about is opposition to the policies of Israel - in fact, opposition to their own hawkish version of the policies of Israel. They're Israeli government lobbies, essentially ..."135 Hence they readily, even eagerly engage in a "vulgar exploitation of the Holocaust ... to justify oppressive control over others." ${ }^{366}$ The Shoah is "very consciously manipulated," Chomsky tells Barsamian in Chronicles of Dissent. "I mean, it's quite certainly real, there's no question about that, but it is also undoubted that they manipulate it, in fact they say so. ... That kind of manipulation is really sick." ${ }^{137}$

Probably the most frequent example he cites of such Holocaust "manipulation" is the first, in a historical sense: the Zionist exploitation of both the Holocaust and its "wretched survivors"138 in the immediate postwar period, to bolster Jewish immigration to Palestine at the expense of other possible destinations. "... It is likely that many - perhaps most - [survivors] would have chosen to come to the United States had this opportunity been offered, but the Zionist movement, including American Zionists, preferred that they settle in a Jewish state, a story being relived today [in the 1980s] with Jewish emigrants from the USSR."139 In Propaganda and the Public Mind, he describes "people dying in displaced persons camps. The Jewish community made virtually no effort to try to have them admitted to the United States," with the exception of "the American Council for Judaism, which is off the main spectrum and was anti-Zionist. But the major Jewish organizations didn't do much. In fact, they did very little, and very few Holocaust victims made it to the US." ${ }^{140}$ Anti-Semitism is part of the explanation, and Chomsky describes contemporary personal experiences of it in these passages and elsewhere. But he clearly considers the influence of "Zionist emissaries [who] took over the camps," and their supporters in diaspora communities, to have been the primary factor. ${ }^{141}$

The stance of successive US governments toward the Holocaust has been similarly unprincipled, in Chomsky's view. Only after the Six-Day War, with the forging of an alliance with Israel as an American proxy in the Middle East, did

you start getting concern about the Holocaust. Before that, when people [in the US] could have actually done something for Holocaust victims - say, in the late 1940s - they didn't do anything. That changed after 1967. Now you have Holocaust museums all over the country. It's the biggest issue, and you have to study it everywhere, mourn it. But not when you could have done something about it. ${ }^{142}$

genocide which was in fact quite comparable to the Holocaust. If they want to publish their disgraceful lies, they should have the right to do so. If they were brought to court, I would defend their right to say what they want. People who are opposed to freedom of speech, or who have their own motives for trying to silence critics, will naturally turn this into whatever they want to." Chomsky, Chronicles of Dissent, 261-262.

${ }^{135}$ Chomsky, Understanding Power, 52.

${ }^{136}$ Chomsky, How the World Works, 271.

${ }^{137}$ Chomsky, Chronicles of Dissent, 70. Chomsky also contrasts "Israelis who think they can kill anybody, because they think that they have the New York Times, Yad Vashem and the Holocaust Museum behind them" (Chomsky, The Common Good, 97) with more honorable Jewish/Zionist voices, such as Nahum Goldmann, a "very conservative and very honest Zionist leader" (Chomsky, Chronicles of Dissent, 70) who served as "President of the World Zionist Organization from 1956 to 1968" (Chomsky, The Fateful Triangle, 98). "At the beginning of the Jewish New Year, in October 1981, he wrote: 'We will have to understand that Jewish suffering during the Holocaust no longer will serve as a protection, and we certainly must refrain from using the argument of the Holocaust to justify whatever we may do. To use the Holocaust as an excuse for the bombing of Lebanon, for instance, as Menachem Begin does, is a kind of "Hillul Hashem" [sacrilege], a banalization of the sacred tragedy of the Shoah, which must not be misused to justify politically doubtful and morally indefensible policies'"' (Chomsky, The Fateful Triangle, 98).

${ }^{138}$ Chomsky, The Fateful Triangle, 92.

${ }^{139}$ Ibid., 93.

${ }^{140}$ Chomsky, Propaganda and the Public Mind, 212.

${ }^{141}$ Chomsky and Pappé, On Palestine, 44.

${ }^{142}$ Chomsky, What We Say Goes, 128-129. 
He allows that "a kind of guilt feeling [could also be] involved, because the role of the United States during the Holocaust was awful, before and during. They didn't act to save Jews, and they could have in many respects." 143

Thus, as throughout his voluminous writings, interviews, and public talks on diverse subjects, Chomsky emphasizes self-interest, intellectual inconsistency, and moral hypocrisy and cowardice. In this case as in others, it leads him to focus on the political manipulation of Holocaust memory, rather than the facts of the Holocaust. The latter, however, he does not dispute, whatever the insinuations of his many detractors.

\section{Conclusion}

Noam Chomsky's approach to the discourse of "genocide" may best be described as conflicted. On one hand, he is justifiably cynical about the manipulative and politicized ways in which the term has often been employed, notably by those in positions of political power and media prominence. This is intensified by the term's deployment against designated enemies (frequently in the context of "humanitarian" interventions); and, contrastingly but correspondingly, the resolute avoidance of "genocide" to inure great powers and their allies to condemnation, and to evade a moral reckoning with the consequences of their own actions, past and present. In one of his most recent comments on the subject, in the foreword to Herman \& Peterson's The Politics of Genocide, Chomsky even suggests that the term should be "expunge[d] ... from the vocabulary," until these self-serving manipulations can be addressed and rectified.

No-one would expect the modern era's most renowned linguistic scholar to be inattentive to language, and Chomsky's critique displays a profound concern with the way political language can be twisted and abused. At the same time, his activist sensibility, combined with the extraordinary rhetorical power of "genocide," leads him to a passing - but cumulatively significant - deployment of the term in his huge corpus of work. By referencing a few key statements and assembling numerous fragments, it is possible to discern a framing that favors a totalized or near-totalized understanding of the concept. However, with the exception of Nazi genocide, the destruction of indigenous peoples in the Americas, and possible future genocides, Chomsky's use of "genocide" is hedged with key reservations and qualifications: one is much more likely to find references to "near-genocide," "virtual genocide," or "approaching genocide," and he is readier to cite others' claims of genocide, albeit supportively, than to advance them without the attendant quotation marks.

Chomsky, then, offers a reasonably coherent and often forceful critique of the misuse of "genocide," and he also uses it for rhetorical and political effect, with the caveats noted. But this is as far as he has been interested and prepared to go. Unlike a couple of his coauthors (Herman and Pappé), Chomsky displays no particular desire to engage meaningfully or systematically with the genocide framing, or to analyze its applications and possible utility. For the most part, one explores this aspect of his writing and speaking not to understand genocide as a concept, but to better understand Chomsky.

But this would be an unsatisfactory note to end on. Chomsky is hardly the first or the only political critic to evince skepticism toward "genocide," and to downplay or avoid it in his own work. To the extent that Chomsky has addressed it, he has provided some useful insights into how, like the other politically-loaded terminology he analyzes, it has been prone to misrepresentation, evasion, and obfuscation, often for nefarious reasons. Much more significant is the formative value of his decades of critique in helping generations of questing, activist-inclined minds - including my own - to penetrate the layers of lies and propaganda that envelop us. Many of us would be less hesitant to label as "genocide" atrocities for which Chomsky generally adopts different terms, or to which he assigns a "genocide" framing only with qualifications. In so doing, though, we would be well advised to draw on Chomsky's painstaking, exhaustive documentation and dissection of such mass crimes - from East Timor to Guatemala and El Salvador, and to varied forms of structural

${ }^{143}$ Chomsky, Chronicles of Dissent, 71-72. 
and environmental violence. His is a major, even unparalleled contribution to the study of mass atrocities worldwide, and for this he merits recognition and gratitude.

\section{Bibliography}

Achbar, Mark, ed. Manufacturing Consent: Noam Chomsky and the Media. Montréal: Black Rose Books, 1994.

Atwood, Breanna. "Khmer Rouge: Evolution of the Academic Debate," March 2010, accessed February 9, 2020, http://digitalcommons.calpoly.edu/cgi/viewcontent. cgi? article $=1004 \&$ context $=$ histsp.

Barsamian, David, ed. Stenographers to Power: Media and Propaganda. Monroe: Common Courage Press, 1992.

Beachler, Donald W. "Arguing about Cambodia: Genocide and Political Interest." In The Genocide Debate: Politicians, Academics, and Victims by Donald W. Beachler, 35-58. Basingstoke: Palgrave Macmillan, 2011.

Becker, Stuart Alan. "Noam Chomsky Maintains the Rage." The Phnom Penh Post, October 5, 2010, accessed February 9, 2020, https://www.phnompenhpost.com/national/noam-chomskymaintains-rage.

Cain, Patrick. "Kosovo: Noam Chomsky Interviewed by Patrick Cain." The Activist, June 1999, accessed February 6, 2020, https://chomsky.info/199906__.

Chomsky, Noam. 9/11. New York: Seven Stories Press, 2002.

-------. American Power and the New Mandarins. New York: Pantheon Books, 1969.

--------. Chomsky on Anarchism, edited by Barry Pateman. Edinburgh: AK Press, 2005.

---------. The Chomsky Reader, edited by James Peck. New York: Pantheon Books, 1987.

------. Chronicles of Dissent: Interviews with David Barsamian. Vancouver: New Star Books, 1992.

-------. Class Warfare. Monroe: Common Courage Press, 1996.

----.-. The Common Good. Tucson: Odonian Press, 1998.

------. The Culture of Terrorism. Boston: South End Press, 1988.

-------. Deterring Democracy. London: Verso, 1991.

--------. The Essential Chomsky, edited by Anthony Arnove. New York: The New Press, 2008.

---------. The Fateful Triangle: Israel, the United States, and the Palestinians. Montréal: Black Rose Books, 1984.

---------. For Reasons of State. New York: Vintage Books, 1973.

--------. Foreword to The Politics of Genocide, by Edward S. Herman and David Peterson, 7-12. New York: Monthly Review Press, 2010.

--------. Hegemony of Survival: America's Quest for Global Dominance. New York: Metropolitan Books, 2003.

-----.- Hopes and Prospects. London: Hamish Hamilton, 2010.

--------. How the World Works. Berkeley: The Real Story Press, 2011.

-------. "Humanitarian Intervention." Boston Review, 18 (December 1993-January 1994), 3-6.

--------. Imperial Ambitions: Conversations with Noam Chomsky on the Post-9/11 World. London: Hamish Hamilton, 2005.

-------. Interventions. San Francisco: City Lights Books, 2007.

--------. Keeping the Rabble in Line. Monroe: Common Courage Press, 1994.

-------. Making the Future: Occupations, Interventions, Empire and Resistance. San Francisco: City Lights Books, 2012.

-------. Middle East Illusions. Lanham: Rowman \& Littlefield, 2003.

-------. Necessary Illusions: Thought Control in Democratic Societies. Montréal: CBC Enterprises, 1989.

. A New Generation Draws the Line: Kosovo, East Timor, and the Standards of the West. London: Verso, 2000.

------.. On Power and Ideology: The Managua Lectures. Boston: South End Press, 1987.

--------. Peace in the Middle East? Reflections on Justice and Nationhood. New York: Vintage Books, 1974.

--------. Power and Terror: Post-9/11 Talks and Interviews, edited by John Junkerman and Takei 
Masakazu. New York: Seven Stories Press, 2013.

--------. Power Systems: Conversations on Global Democratic Uprisings and the New Challenges to the US Empire. New York: Metropolitan Books, 2013.

-------. Powers and Prospects: Reflections on Human Nature and the Social Order. Boston: South End Press, 1996.

--------. Propaganda and the Public Mind. Boston: South End Press, 2001.

-------. The Prosperous Few and the Restless Many. Berkeley: Odonion Press, 1993.

-------. Rogue States: The Rule of Force in World Affairs. Cambridge: South End Press, 2000.

--------. Turning the Tide: US Intervention in Central America and the Struggle for Peace. Boston: South End Press, 1985.

---------. Understanding Power: The Indispensable Chomsky, edited by Peter R. Mitchell and John Schoeffel. New York: The New Press, 2002.

---------. What Uncle Sam Really Wants. Berkeley: Odonian Press, 1992.

--------. What We Say Goes: Conversations on US Power in a Changing World. London: Allen \& Unwin, 2007.

--------. World Orders, Old and New. New York: Columbia University Press, 1994.

-----. Year 501: The Conquest Continues. Boston: South End Press, 1993.

Chomsky, Noam and Andre Vltchek. On Western Terrorism: From Hiroshima to Drone Warfare. London: Pluto Press, 2013. Doi: 10.2307/j.ctt1kzcbwh

Chomsky, Noam and Edward S. Herman. After the Cataclysm: Postwar Indochina and the Reconstruction of Imperial Ideology. Montréal: Black Rose Books, 1979.

. "Distortions at Fourth Hand," The Nation, June 6, 1977, accessed February 9, 2020, https:// chomsky.info/19770625/

-. The Washington Connection and Third World Fascism. Boston: South End Press, 1979.

Chomsky, Noam and Ilan Pappé. Gaza in Crisis: Reflections on Israel's War against the Palestinians. London: Hamish Hamilton, 2010.

-----.. On Palestine. Chicago: Haymarket Books, 2015.

"Counter-Revolutionary Violence: Bloodbaths in Fact and Propaganda." Wikipedia, accessed March 30, 2019, https://en.wikipedia.org/wiki/Counter-Revolutionary Violence: Bloodbaths in Fact \%26 Propaganda.

Eder, Richard "Chomsky Stirs French Storm in a Demitasse." The New York Times, January 1, 1981, accessed March 23, 2019, http://www.nytimes.com/1981/01/01world/chomsky-stirsfrench-storm-in-a-demitasse.html.

"Faurisson Affair." Wikipedia, accessed February 10, 2020, https://en.wikipedia.org/wiki/ Faurisson affair.

Herman, Edward S. and David Peterson. The Politics of Genocide. New York: Monthly Review Press, 2010.

Herman, Edward S. and Noam Chomsky. Manufacturing Consent: The Political Economy of the Mass Media. New York: Pantheon Books, 1988.

Horowitz, David. "The Sick Mind of Noam Chomsky." Salon.com, September 26, 2001, accessed March 23, 2019, https://www.salon.com/2001/09/26/treason 2/.

Jones, Adam. Beyond the Barricades: Nicaragua and the Struggle for the Sandinista Press, 1979-1998. Athens: Ohio University Press, 2002.

--------. "Denying Rwanda." In The Scourge of Genocide: Essays and Reflections, edited by Adam Jones, 346-359. London: Routledge, 2012.

---------. "Preface." In Gender Inclusive: Essays on Violence, Men, and Feminist International Relations, edited by Adam Jones, xi-xix, London: Routledge, 2009.

---------. "Seized of Sorrow." In Advancing Genocide Studies: Personal Accounts and Insights from Scholars in the Field, edited by Samuel Totten, 57-77. New Brunswick: Transaction Publishers, 2015 Doi: 10.4324/9781315083001-3.

Massing, Michael. “Think Tank: Surprise Best Seller Blames US.” The New York Times, May 4, 2002, accessed March 23, 2019, http://www.nytimes.com/2002/05/04/books/think-tank-surprisebest-seller-blames-us-html. 
McLeod, George. "Tribunal Ignoring US Role, Says Chomsky." The Phnom Penh Post, March 27, 2009, accessed February 9, 2020, https://www.phnompenhpost.com/national/tribunalignoring-us-role-says-chomsky.

Monbiot, George. "Correspondence with Noam Chomsky," May 21, 2012, accessed March 31, 2019, https://www.monbiot.com/2012/05/21/2181/. 